IZA DP No. 5403

Chutes and Ladders:

Dual Tracks and the Motherhood Dip

Daniel Fernández-Kranz

Aitor Lacuesta

Núria Rodríguez-Planas

December 2010 


\title{
Chutes and Ladders: Dual Tracks and the Motherhood Dip
}

\author{
Daniel Fernández-Kranz \\ IE Business School \\ Aitor Lacuesta \\ Banco de España \\ Núria Rodríguez-Planas \\ Universitat Autònoma de Barcelona, \\ MOVE, FEDEA and IZA
}

\author{
Discussion Paper No. 5403 \\ December 2010
}

\author{
IZA \\ P.O. Box 7240 \\ 53072 Bonn \\ Germany \\ Phone: +49-228-3894-0 \\ Fax: +49-228-3894-180 \\ E-mail: iza@iza.org
}

\begin{abstract}
Any opinions expressed here are those of the author(s) and not those of IZA. Research published in this series may include views on policy, but the institute itself takes no institutional policy positions.

The Institute for the Study of Labor (IZA) in Bonn is a local and virtual international research center and a place of communication between science, politics and business. IZA is an independent nonprofit organization supported by Deutsche Post Foundation. The center is associated with the University of Bonn and offers a stimulating research environment through its international network, workshops and conferences, data service, project support, research visits and doctoral program. IZA engages in (i) original and internationally competitive research in all fields of labor economics, (ii) development of policy concepts, and (iii) dissemination of research results and concepts to the interested public.
\end{abstract}

IZA Discussion Papers often represent preliminary work and are circulated to encourage discussion. Citation of such a paper should account for its provisional character. A revised version may be available directly from the author. 


\begin{abstract}

\section{Chutes and Ladders: Dual Tracks and the Motherhood Dip ${ }^{*}$}

Using rich panel data recently available from Spanish Social Security records, we find that a negative motherhood earnings differential of 2.3 log points remains even after controlling for both individual- and firm-level unobserved heterogeneity. The analysis of the mothers and childless women's earnings trajectories over time reveals that "mothers to be" experience important earnings increases (of up to 6 log points) several years prior to giving birth to their first child. However, this earnings' advantage gets seriously hit right after birth, and it is not until nine years later that mothers' earnings return to their pre-birth (relative) levels. The study finds that heterogeneity matters as most of the motherhood penalty and earnings' dip is driven by mothers working in the primary labor market (with permanent contracts). For these women, much of the earnings losses occur because mothers change employers to work parttime, or (if they stay with their former employer) they take leave of absence. An instrumental variable approach is used to address concerns of selection into type of contract. We exploit variation in the amount, timing and profiling of subsidies offered to firms when hiring permanent workers, a policy that started to be implemented in Spain in 1997.
\end{abstract}

JEL Classification: J13, J16, J21, J22, J31, J62, C23

Keywords: earnings trajectories, individual- and firm-level fixed-effects estimator, permanent and fixed-term contracts, underlying channels

Corresponding author:

Núria Rodríguez-Planas

Unitat de Fonaments de l'Anàlisi Econòmica

Edifici B

Universitat Autònoma de Barcelona

08193 Bellaterra

Spain

E-mail: Nuria.Rodriguez@uab.es

\footnotetext{
* We are extremely grateful to participants of a seminar at the Bank of Spain for helpful comments. Núria Rodríguez-Planas acknowledges financial support from the Spanish ministry of Education and Science (grant SEJ2006-712), the Generalitat de Catalunya (grant SGR2005-712), and Barcelona Economics XREA - Program. Finally, Núria Rodríguez-Planas is affiliated to IZA in Bonn, FEDEA in Madrid, and MOVE, Graduate School of Economics in Barcelona, and greatly appreciates their support. The opinions and analyses in this paper are the responsibility of the authors and, therefore, do not necessarily coincide with those of the Banco de España or the Eurosystem.
} 


\section{Introduction}

In the light of the low fertility trends in many industrialized countries, and the relative importance of women's earnings in the economic support of their families, many researchers have increasingly become interested in analyzing the earnings differential between mothers and childless women and its causes. To disentangle the channels through which the (raw) motherhood earnings' gap emerges is the first step for designing policies which aim at improving the conditions of working mothers, in particular, and female workers, more generally.

Recently, several authors have investigated whether the effect of motherhood on earnings differs by skill level, or mothers' age. ${ }^{1}$ However, there has been little attention, thus far, on the differential effect of motherhood across different segments of the labor market, despite the growing concern that many Continental European countries (such as, France, Germany, Portugal, Italy, and Spain) have experienced a deepening segmentation of their labor markets with 'insiders' (those with permanent contracts), on the one side, enjoying high level of employment protection, decent jobs and generous benefits, and 'outsiders' (those with fixed-term contracts), on the other, having poor labor market perspectives and low remuneration. ${ }^{2}$

The contribution of this paper is threefold. First, we examine the implications of having a child on women's subsequent earnings controlling for both individual- and firm-level unobserved heterogeneity (through fixed-effects). Second, we identify the

\footnotetext{
${ }^{1}$ Taniguchi, 1999; Todd, 2001; Budig and England, 2001; Anderson et al., 2002; Anderson et al., 2003; Amuedo-Dorantes and Kimmel, 2005; Loughren and Zissimopoulus, 2009; Kunze and Kenneth, 2009; and Elwood et al., 2010 have analyzed the motherhood differential by skill or educational level. With the exception of Ellwood et al., 2010, they find that the wage penalty declines with schooling. At the same time, other authors have analyzed whether there are motherhood differential effects by mothers' agesee, Geronimus and Korenman, 1992; Hotz et al., 1997; Hoffman, 1998; Taniguchi, 1999; Cherlin, 2001; Hotz et al., 2005; Amuedo-Dorantes and Kimmel, 2005; and Miller, 2008. Although earlier literature suggested that adolescent childbearing is more costly in terms of mothers' future earnings, recent studies have undermined these results. Analyzing the effect of timing more broadly, Taniguchi, 1999; Miller, 2008; and Herr, 2007, report that delaying birth reduces the cost of childbearing.

${ }_{2}^{2}$ See Bentolila and Dolado, 1994; Blanchard and Landier, 2002; Dolado, et al., 2002; Cahuc and Kramarz, 2004; Beninger, 2005; Eichhorst, 2007; and Dolado, et al., 2007, among others.
} 
differential earnings trajectories (again correcting for both individual- and firm-level fixed-effects) of mothers relative to childless women and explore whether earnings changes precede or follow childbearing-following a strategy similar to Jacobson, Lalonde, and Sullivan, 1993; and Hijzen, Upward, and Wright, 2008. Finally, we explore whether the motherhood earnings (and earnings trajectory) differential differs across two groups of workers, those with and without a permanent contract. For this purpose, we use a rich longitudinal dataset obtained from the Spanish Social Security records that covers workers' employment history from 1985 to 2006, and has only recently been available to researchers in Spain. Our analysis focuses on adult women between 24 and 45 years old who worked at some point in time between 1996 and 2006. ${ }^{3}$ To address concerns of selection into the type of contract, we exploit the variation in the amount, timing and profiling of subsidies offered to firms when hiring permanent workers, a policy that started to be implemented in Spain in 1997.

The paper provides four novel results. First, we find that a (far from insignificant) motherhood earnings differential of 2.3 log points remains even after controlling for individual- and firm-level observed and (time invariant) unobserved heterogeneity. To put this coefficient into context, becoming a mother in Spain is equivalent to a net loss in annual earnings as large as one third the gains from the returns to a year of schooling. This estimate is close to the one obtained from the individual-fixed effects specification after controlling for observable job characteristics. This second finding is important because it validates earlier individual fixed-effects findings from the literature as long they control for job characteristics. Third, the analysis of the earnings trajectories reveals that prior to giving birth, "mothers to be"

\footnotetext{
${ }^{3}$ Although the data set covers employment history from 1985 to 2006, we focus our analysis on the 1996 through 2006 period because type of contract is not available prior to 1996. However, we shall use women's employment history back to 1985 to calculate variables such as labor market experience and tenure.
} 
experience important earnings increases (of up to 6 log points) relative to childless women. However, this earnings' advantage gets seriously hit right after birth, and it is not until nine years later that mothers' earnings return to their pre-birth (relative) levels. Fourth, our analysis finds that much of the differential between mothers and childless women is driven by women working in the primary labor market. For these, about half of the earnings losses occur because mothers change employers to work part-time, or (if they stay with their former employer) they accumulate less experience as they take a leave of absence.

Spain is a suitable case to investigate this issue because of the striking segmentation of its labor market. The Spanish unemployment rate has been extremely high (as much as one fifth of the labor force) for almost two decades (during the 1980s and 1990s), and it is currently at 20\%, the highest in Europe. In addition, an important dual labor market developed after legislation changes in 1984, resulting in the economy with the highest rate of fixed-term contracts in Europe for the last two decades (over one third of all contracts are fixed-term contracts). This bleak picture of the Spanish labor market—with widespread job precariousness, high unemployment rate, and lack of access to good part-time jobs-, does not make for a family-friendly country (as discussed by de la Rica and Ferrero, 2003; and Esping-Andersen, Güell, and Brodmann, 2007, among others). As a consequence, Spain not only has one of the lowest fertility rates worldwide, but it is one of the countries in which women postpone having their first child to a relatively late age. Analyzing and understanding the consequences of motherhood on women's earnings trajectories under such circumstances is, thus, of highest policy relevance.

The paper is organized as follows. The next section presents an overview of the literature. Section III describes the Spanish institutional background. Section IV 
presents the data and the descriptive statistics. Section V explains the methodological approach, and analyzes the results. Section VI concludes.

\section{Literature on Motherhood Wage Gap}

Many researchers have increasingly become interested in analyzing the effect of motherhood on women's careers by analyzing how motherhood affects women's earnings. While the earliest studies focused on the US (Korenman and Neumark, 1992; Waldfogel, 1997, 1998a, 1998b; Lundberg and Rose, 2000; Budig and England, 2001; Anderson, et al., 2002, 2003; Edwards, 2005; and Gangl and Ziefle, 2009) and the UK (Waldfogel, 1995, and 1998a; Joshi, et al., 1999; and Gangl and Ziefle, 2009), the more recent literature has evaluated the child penalty in other industrialized countries, such as Canada (Phipps, Burton and Lethbrigde, 2001); Denmark (Rosholm and Smith, 1996; Datta Gupta and Smith, 2002; and Nielsen, Simonsen, and Verner, 2004); Spain (Molina and Motuenga, 2008); Sweden (Albrecht et al., 1999); and West Germany (Kunze, 2002; Ondrich, Spiess, and Yang, 2003; Kunze and Ejrnaes, 2004; Ziefle, 2004; and Gangl and Ziefle, 2009), among others. ${ }^{4}$

What explains the motherhood wage gap? In many studies, part of the motherhood wage gap is explained by differences in the observed human capital variables between mothers and childless female workers, such as education, work experience and mothers' work interruptions and subsequent entry into part-time jobs. ${ }^{5}$ In other studies, the motherhood wage gap decreases as one controls for women shifting to occupations and industries offering predictable work schedules or job security (Desai and Waite 1991). In addition, job changes may imply loss of firm-, occupation-, or

\footnotetext{
${ }^{4}$ See the end of next section for detailed explanation of Molina and Motuenga's findings.

${ }^{5}$ See Moffit, 1984; Joshi, 1990; Blackburn, et al., 1992; Korenman and David Neumark, 1992; Neumark and Korenman, 1994; Waldfogel, 1995, 1997, and 1998; Hotz,et al., 1997; Angrist and Evans, 1998; Joshi, et al., 1999; Drobnic, et al., 1999; Lundberg and Rose, 2000; Budig and England, 2001; and Anderson, et al., 2003, among others.
} 
industry-specific human capital and will then similarly result in wage losses (Budig and England 2001; Jacobs 1997; Mertens et al., 1995; Waldfogel 1998). Finally, some studies have found that an important child penalty persists after controlling for these variables if not for all workers for some subset, such as the private-sector workers (see Nielsen, Simonsen, and Verner, 2004; and Datta Gupta and Smith, 2000). ${ }^{6}$

At the end, most studies find a significant unexplained child penalty, the magnitude of which differs substantially across the different countries since it ranges between 0 and 8 percent. While some of the differences in the results are explained by countries' institutional and cultural differences, and the amount of information available on workers, jobs, and labor market characteristics in the different datasets used, as well as the methodology used, several identification problems within this literature are difficult to overcome. Most of this literature compares the hourly wages of mothers with childless female workers after controlling for all observable characteristics, acknowledging that individual unobserved heterogeneity may still prevail, as women deciding to have children may have different tastes and preferences about work than do childless female workers. If there are unobserved quality differences between mothers and childless female workers, results from cross-sectional studies of the family gap will reflect an omitted variable bias. Nevertheless, many of the studies in this literature have been estimated on cross-sectional samples—see, for example, Korenman and Neumark, 1992; Waldfogel, 1997, 1998; Joshi, Paci and Waldfogel, 1999; Lundberg and Rose, 2000; Budig and England, 2001; Phipps, Burton and Lethbrigde, 2001; Loughran and Zissimopoulos, 2009; among others. One way to address the unobserved heterogeneity problem is to use panel data and to estimate an individual fixed-effects-'within' estimator, in which case, the effect of motherhood on wages is identified through those

\footnotetext{
${ }^{6}$ In contrast, Albrecht et al., 1999 and Datta Gupta and Smith, 2000, find that in Sweden and Denmark women in the public sector get a premium from having children when interruptions are controlled for.
} 
female workers who become mothers—see Korenman and Neumark 1991; Waldfogel 1997, 1998; Taniguchi 1999; Lundberg and Rose 2002; Anderson, Binder, and Krause 2002, 2003; Amuedo-Dorantes and Kimmel, 2005; Davies and Pierre, 2005; and Gangl and Ziefle, 2009. ${ }^{7,8}$ These studies report reductions in mothers earnings ranging between 3 and $6 \%$ for the first child.

A related problem is the possibility that the wage differential between mothers and childless women is driven by the selection of mothers into firms that pay lower wages. Using a novel matching approach where mothers' wages upon return to work are compared to those of their female colleagues within the same establishment, Beblo et al., 2009, find that selection into establishments is an important explanatory factor for the German family pay gap. In the current paper we solve this problem by controlling for firm heterogeneity through the introduction of firm fixed-effects (on top of individual-fixed effects) in our specifications.

Another problem is measurement errors of wages. As Brownstone and Valletta, 1996, explain, "few studies acknowledge the presence of measurement error, and those that do typically assume that it is in its "classical" form and therefore has limited influence on the parameters estimates if earnings are only used as the dependent

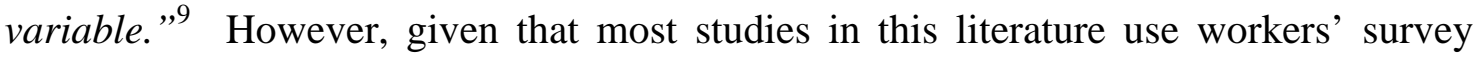
data, measurement errors of hourly wages is a frequent (albeit rarely discussed) concern in this literature. The OECD, 2002, warns about the possibility of having measurement errors in surveys stemming from the fact that the interviewed persons provide direct

\footnotetext{
${ }^{7}$ As is well known, fixed-effect estimates of the effect of childbearing on wages are still subject to bias if individual-level unobserved heterogeneity is not fixed over time.

${ }^{8}$ Alternatively, Korenman and Neumark, 1992, Waldfogel, 1997, and Davies and Pierre, 2005, use firstdifferences to control for the selection of low-wage women into motherhood. On the other hand, Neumark and Korenman, 1994, use data on sisters to control for unobserved family-specific heterogeneity.

9 "Classical" measurement error requires that measurement error be normally distributed with mean zero and constant variance, uncorrelated with true earnings and the values of explanatory variables and uncorrelated over time for a given individual.
} 
information about their own wages, rather than their employers, as is the case with matched employer-employee data or social security records. Indeed, Bound et al., 1990, 1994, and Bound and Krueger, 1991, found that measurement error in survey earnings responses is large and not "classical” in the PSID and the CPS-Social Security Records Exact Match files. In addition, Bound et al., 1989, and Duncan and Hill, 1985, and Pischke, 1995, find systematic partial correlations between measurement error in earnings and other observable variables, such as, education, experience, and tenure in the PSID. The measurement error is particularly concerning in those studies where the wage rate is calculated as weekly (or annual) earnings divided by weekly (or annual) hours worked, as opposed to the pay rate available only for hourly workers, because of the added noise in the hours worked variable. Unfortunately, this is the most frequent outcome used in the motherhood earnings differential literature. ${ }^{10}$

Another important identification problem is endogenous fertility (or the danger of reverse causation). Since fertility is a choice and the market wage is one component of the "cost" of children, it may be low wages that 'cause' childbearing, not the childbearing that 'causes' low wages. This problem is usually addressed by using an instrumental variables strategy. However, valid instruments are extremely difficult to find. One approach has been to exploit exogenous variation in the tendency to have a third child induced by the gender mix of the first two children (see Rosenzweig and Wolpin, 1980; Bronars and Grogger, 1994; and Angrist and Evans, 1998). However, it is unclear whether these estimated effects would generalize to the effects of first (and second) children. An alternative approach is to use shocks to fertility-such as, miscarriage and undesired childbearing (pregnancy while using contraceptives)—to

\footnotetext{
${ }^{10}$ To avoid the measurement error in hours worked, Lundberg and Rose, 2002, only use the pay rate available in the PSID from hourly and salary workers. However, such approach does not eliminate the problem of measurement error in wages, and introduces a particular selection in the type of workers the analysis focuses on.
} 
generate exogenous variation in the timing of motherhood (see Hotz, McElroy, and Sanders, 2005; and Miller, 2008). This identification strategy is undermined if miscarriages are correlated with unobserved health or if the likelihood of recognizing a miscarriage as such is correlated with unobserved determinants of labor market success. It may also be that the effectiveness of contraception (in terms of both diligence and quality of method) varies with the expected cost of childbearing. More recently, Cristia, 2008, tackles the problem of endogeneity of fertility by focusing on a sample of childless women who sought help with having a first child. While at the time of seeking help, all of the women wanted to have a child; after a certain period, some of them gave birth and others did not. Cristia uses the latter group as the counterfactual to estimate the motherhood earnings differential.

In this paper we account for both individual- and firm-level unobserved heterogeneity by exploiting a rich longitudinal dataset that covers employment history from 1985 to 2006, and has only recently been available to researchers in Spain. In addition, as our data comes from Social Security records, our measure of annual earnings does not have the problem of measurement error due to recall bias or nonresponse. To overcome a problem with measurement error of contractual hours in our data set, we focus our analysis on yearly earnings as opposed to hourly wages. As explained by Fernández-Kranz and Rodríguez-Planas, 2010, in the Spanish Social Security records contractual hours underestimate hours worked because employers have an incentive to underreport contractual hours to reduce total labor costs, and (albeit illegal) they are more able to do so with their more vulnerable workers, such as those working flexible time or part-time jobs (since they are less protected by the law and the unions). Since mothers are much more likely to have flexible work arrangements than childless women, we are concerned that by estimating and using hourly wages as our 
outcome variable we may overestimate hourly wages for the former relative to the latter. To overcome this problem, we use yearly earnings from Social Security records as our outcome variable and refocus the analysis from productivity effects to both productivity and labor supply effects. We then disentangle how much of the motherhood earnings differential is explained by mothers': (i) temporarily interrupting their career due to childcare (by controlling by actual experience); (ii) reducing their work schedule (to part-time work); (iii) shifting to more family-friendly occupations, industries, and (iv) shifting employers. ${ }^{11}$ Given the strong duality of the Spanish labor market, the analysis is done separately by type of contract. To correct for possible endogeneity problems by type of contract, we use legislative variation across regions and years on subsidies to permanent contracts for different age groups of workers to instrument for type of contract.

We do not model endogenous fertility. Therefore, we do not strictly identify the causal impact on earnings of becoming a mother. However, considering that longitudinal estimates more closely approximate average treatment effects among the treated than among random draws from the population (Hirsch, 2005), we believe that our estimates address some of the issues raised in this literature and bring new evidence on the situation of mothers in segmented labor markets in general, and in Spain, more specifically.

In addition, our analysis also identifies different wage trajectories by motherhood status and type of contract. While fixed effects are essentially before-after strategies that control for any unchanging and unmeasured differences across individuals; they do not fully solve the endogeneity problem. In contrast, trajectories

\footnotetext{
${ }^{11}$ Part-time workers are those who work less than 30 hours a week. Because we identify part-time status by whether the worker has a part-time contract, problems of measurement error of hours worked when using contractual hours is not an issue in our analysis.
} 
can themselves be observed and one can look for anomalous breaks in patterns that differ with childbirth, noting whether wage changes preceded or followed childbearing.

\section{Institutional Background}

Most of the existing literature on motherhood wage differentials uses data from Denmark, Germany, Sweden, the United Kingdom, or the United States, where the incidence of female temporary or fixed-term employment is relatively low. Table 1 shows statistics for some of these countries and illustrates that Spain is among the countries with a lower incidence of part-time work combined with an extremely high incidence of fixed-term employment (OECD, 2008). These figures highlight that the unique specificities of the Spanish labor market may lead to significant differences on the effects of childcare interruptions and the child earnings differential. Below, we briefly discuss the institutional background of the Spanish labor market.

The two most common forms of flexible work arrangements (fixed-term contracts and part-time work) have evolved quite differently in Spain over the last two decades. Both types of contracts were first regulated by law in 1984 with the objective of adding flexibility and promoting employment in a rigid labor market with stringent employment protection legislation and high levels of unemployment. While fixed-term employment soared, the growth in part-time employment was modest, at most. As a result, since the early 1990s, fixed-term employment represents one third of the Spanish labor force (by far, the highest share among European countries), whereas the share of part-time employment is below one tenth of the labor force (far from the EU average of $18 \%)$.

\section{A Dual Labor Market}

Prior to 1984, most contracts in Spain were permanent contracts. With such contracts, the costs of dismissing a worker were high (up to 45 days of wages per year worked if 
the worker appealed to Court and the dismissal was declared "unfair", with a limit of 24 months' wages). ${ }^{12}$ In 1984, in a context of high unemployment and given that an across-the-board reduction of dismissal costs was politically unfeasible; the use of temporary contracts was liberalized. As such, fixed-term contracts for regular activities entailed much lower severance payments than permanent contracts (initially of 12 days per year worker, zero if the firm waited until expiration), and their termination could not be appealed to labor courts (in contrast with their permanent counterpart). However, temporary contracts could only be used up to a maximum of three consecutive years.

After the 1984 regulation change, fixed-term employment soared and, since the early 1990s, they have represented one third of the Spanish labor force. The surge of fixed-term contracts began to be questioned in the late-1980s when experts started to advise against the risk of segmentation with "good" (permanent) jobs and "bad" (fixedterm) jobs-Segura et al., 1991; Bentolila and Dolado, 1992; Jimeno and Toharia, 1993; and Dolado et al., 2002. The concern was that the Spanish labor market would become a dual labor market with workers with fixed-term contracts holding unstable, low protected and poorly paid jobs, while workers with permanent contracts enjoyed protection and presumably also higher wages. According to Bover and Gómez, 2004, between 1985 and 1994, over 95\% of all new hires were employed through temporary contracts and the conversion rate from temporary to permanent contracts was only around $10 \% .^{13}$

The reforms of 1994, 1997, 1999, and 2001 aimed to enhance the use of permanent contracts and reduce its cost. While the 1994 reform tried to limit the use of temporary contracts through ineffective regulation, the more recent reforms increased

\footnotetext{
${ }^{12}$ Izquierdo and Lacuesta, 2006, and Galdón-Sánchez and Güell, 2003, estimate that between 72\% and $75 \%$ of cases that arrived to court were declared "unfair" by Spanish judges.

${ }^{13}$ Once workers have a permanent contract, they will seldomly switch to a temporary one, unless they become unemployed.
} 
the incentives for firms to hire workers in certain population groups using permanent contracts. ${ }^{14,15}$ However, these reforms were quite unsuccessful at reducing the share of temporary contracts in the labor force-see Kugler et al., 2002, and Dolado et al., 2002. Since then, many authors have provided evidence suggesting that the labor market of temporary workers is a secondary labor market in Spain (Jimeno and Toharia, 1993; Amuedo-Dorantes, 2000; Hernanz, 2002; Dolado et al., 2002; De la Rica, 2004; Bover and Gómez, 2004; Güell and Petrongolo, 2007; García-Ferreira and Villanueva, 2007; and Barceló and Villanueva, 2010).

\section{Motherhood and Reconciling Work and Family in Spain}

The evidence suggests that Spain is not a family-friendly country for working parents (and especially mothers). According to Sanchez-Mangas and Sanchez-Marcos, 2008, the following five stylized facts illustrate the challenges that the Spanish society has in reconciling work and family. First, Spain has one of the lowest female employment rates in the OECD. For instance, in 2002, the Spanish female employment rate was $45 \%$, far from the $66 \%$ of the US and the UK, $67 \%$ of Canada, and $73 \%$ of Sweden. Second, Spanish maternity leave is, on average, nine weeks shorter than in most of the European countries (OECD, 2001). Third, the use of formal child-care arrangements for three-year-old children is much less frequent in Spain than in the average European country. This is partly due to the fact that access to day-care for children under three is very scarce in Spain and, being predominantly private, it is also relatively expensive. Thus, it ought not to come as a surprise that babies and toddlers' enrollment rate is low

\footnotetext{
${ }^{14}$ In 1994 new regulations limited the use of temporary employment contracts to seasonal jobs. In practice, employers found ways to get around this restriction and continued to hire workers under temporary contracts for all types of jobs and not just for seasonal jobs.

${ }^{15}$ For instance the 1997 reform reduced unfair dismissal costs by about $25 \%$ and payroll taxes between $40 \%$ and $90 \%$ for newly signed permanent contracts for workers under 30 years of age, over 45 years of age, the long-term unemployed, women under-represented in their occupations, and disabled workers. In addition, this reform reduced unfair dismissal costs by about $45 \%$ and payroll taxes by $50 \%$ for conversions of temporary into permanent contracts for all age groups.
} 
in Spain compared to neighboring countries: as such, in 2001 the proportion of children under the age of three in preschool was only 9 percent in Spain, in sharp contrast with the European average of 25 percent (Gauthier, 2000; and Tietze and Cryer, 1999). Fourth, the 2004 Spanish Labor Population Survey indicates that 65\% of women aged 45 and younger reported family responsibilities as their main reason for not participating in the labor market (Herrarte-Sánchez, Moral-Carcedo, and SáezFernández, 2007). Last, but not least, at 1.25 in 2002, the Spanish fertility rate is one of the lowest fertility rate among the OECD countries_compared, for example, with 2 in the US or 1.6 in the UK-, which is also indicative of the difficulties of reconciling work and family in Spain. As a consequence, Spain not only has one of the lowest fertility rates worldwide, but it is one of the countries in which women postpone having their first child to a relatively late age (see Figure 1). Previous research has found that one of the reasons to delay marriage and fertility in Spain is that female workers prefer to wait and have a protected job before engaging in motherhood (Ahn and Mira, 2001; Baizan, 2004; de la Rica and Iza, 2005; Gutierrez-Domenech, 2005; García Ferreira and Villanueva, 2007).

Despite the striking segmentation of the Spanish labor market, little is known about the motherhood wage differential in the primary versus the secondary labor market in any country, in general, and in Spain, more specifically. To the best of our knowledge the only paper studying the motherhood wage differential in Spain is the one of Molina and Montuenga, 2009. Using the 1994-2001 European Household Panel and individualfixed effect estimators, these authors find evidence of a wage motherhood penalty in Spain. Moreover, they find that there is positive self-selection into motherhood in Spain, and that female workers with higher human capital accumulation and better paid jobs are more likely to become mothers. Methodologically, our work differs from 
Molina and Motuenga, 2009 study in the following four ways: First, we estimate not only the effect of motherhood on earnings, but also on women's earnings profile before and after birth. Second, in addition to individual-level fixed-effects, we estimate models with firm-level fixed effects. Third, we estimate the motherhood differential by type of contract, correcting for possible endogeneity by type of contract. Finally, our sample sizes are considerably larger than theirs. While our findings are consistent with those of Molina and Motuenga, 2009, they bring to light important novel results, such as, the existence of motherhood dip in earnings' trajectories, the differential motherhood effect by type of contract, and the channels through which this emerges.

\section{The Data and Descriptive Statistics}

We use data from the 2006 wave of the Continuous Sample of Working Histories (hereafter $\mathrm{CSWH}$ ), which is a $4 \%$ non-stratified random sample of the population registered with the Social Security Administration in 2006. ${ }^{16}$ The CSWH consists of nearly 1.1 million individuals and provides the complete labor market history of the selected individuals back to $1967 .{ }^{17}$ It provides information on: (1) socio-demographic characteristics of the worker (such as, sex, education, nationality, province of residence, number of children in the household and their date of birth); (2) worker's job information (such as, the type of contract-fixed-term versus permanent contract-, the part-time status, the occupation, and the dates the employment spell started and ended, and the monthly earnings); (3) employer's information (such as, industry—defined at

\footnotetext{
${ }^{16}$ This includes any person that has either contributed to the Social Security or has received a pension or unemployment benefits from the Social Security during 2006. These data are extracted from administrative records from the Social Security, the Municipal Registry of Inhabitants, and the Spanish Internal Revenue Service. For a description of the CSWH and the sampling strategy, see Argimón and González, 2006.

${ }^{17}$ We have information on the dates the employment spell started and ended, but for those not working we do not know whether this is because they are studying, they are unemployed or another reason (the unemployed appear as such in the dataset only as long as they receive unemployment benefits from the Social Security but not if they are not eligible for such benefits). Therefore, we record spells of non-work as the time the person is not employed.
} 
the three-digits Spanish classification code or NACE—, public versus private sector-, the number of workers in the firm, and the location—at the province level). Although not reported in the CSWH, other variables such as working experience (in full- and part-time work) and tenure can be easily calculated. In addition, information on the individual's education level, and the number and date of birth of children living in the household at the time of the interview (including but not distinguishing own natural, adopted, step and foster children) is also available in the Spanish Municipal Registry of Inhabitants, which is matched at the person level with the Social Security records.

Because the CSWH does not have reliable information on type of contract prior to 1996, our analysis focuses on work histories from 1996 to 2006. However, we use information back to 1985 to calculate variables such as workers' experience and tenure. Therefore, although our motherhood earnings gap analysis focuses on the period from 1996 to 2006, we use information on the workers' employment experience and tenure back to 1985.

Following Connolly and Gregory 2009, we restrict our sample to women whose full labor market history to date can be observed. We focus our analysis on wage and salary workers, that is, we exclude from the analysis self-employed individuals. ${ }^{18}$ We confine our selection to birth cohorts between 1961 and 1971, implying that women in our sample will be aged between 25 and 45 years. We restricted our selection to women in these cohorts to ensure that childless women in our sample would be very unlikely to become mothers even after $2006{ }^{19}$ In addition, we confine our analysis to women living in households of five or fewer members (96.5\% of the sample). The

\footnotetext{
${ }^{18}$ If the worker held more than one job, the analysis focuses on her main job, defined as the job in which the worker has a permanent contract-if she has one-, and in the case of multiple jobs with the same type of contract, the one for which the individual worked the largest number of days in a given year.

${ }^{19}$ Notice that women in our sample are between 35 and 45 years old in 2006, implying that childless women in our sample are very unlikely to become mothers, as only $4 \%$ of mother in the CSWH had their first child at 35 years old or older.
} 
reason for this restriction is that it guarantees that we have accurate information on the number and age of children, which is unavailable in the CSWH but can be obtained from the Spanish Municipal Registry of Inhabitants. ${ }^{20}$

Finally, our analysis focuses on first birth because it simplifies the estimation strategy. It can be argued that the effect of having a first child is the most important one, given that it applies to a vast majority of women, whereas the effect of having a second or higher order child only applies to a smaller subset of women (Cristia, 2008). Moreover, Shapiro and Mott, 1994, provide strong evidence that labor force status following first birth is an important predictor of lifetime work experience. Because we need to observe mothers for some time prior to having their first child, we restrict the sample of mothers to those observed working one year before the birth of the first child. $^{21}$

This sample selection results in an unbalanced panel of 83,403 observations on 11,046 women, of which 2,347 (21.24\%) are mothers at some point in time by 2006 as shown in Table 2. The percentage of mothers by 2006 is higher among those working with a permanent contract (25.03\%) than those working with a fixed-term contract (15.57\%). Although our econometric analysis focuses on the time period between 1996 and 2006, individuals are in the CSWH between 3 and 21 years, and for an average of 8 years.

Table 2 presents descriptive statistics of the key covariates for the year 2006. The main focus of the present study is to analyze how the earnings trajectories vary for mothers versus childless women and by contract type (fixed-term versus permanent).

\footnotetext{
${ }^{20}$ Although we know who lives in the household and their age, we do not know their relationship with the respondent in the CSWH. According to Lacuesta and Fernandez-Kranz, 2009, the information on family composition is reliable (relative to Census data) for the sub-population of women under 45 years old and for those living in small households. However, for older women and for women living in large households, the data becomes noisier as it is unclear whether the younger person in the household is a descendent or just a roommate.

${ }^{21}$ Again this is not uncommon in the literature, see Beblo et al., 2009.
} 
The data are therefore divided in four groups, classified by motherhood status and type of $_{\text {contract. }}^{22}$ Among the sample under study, we find that those with permanent contracts represent $61.32 \%$ of the sample. However, the percentage of mothers working with a permanent contract $(71.84 \%)$ is considerably higher than the percentage of childless women with permanent contract (58.75\%).

When comparing the variables for mothers and childless women, Table 2 shows that in 2006 mothers with permanent contracts have higher (raw) yearly wages and lower (raw) weekly hours than childless permanent workers. In contrast, the only observed (raw) difference between mothers and childless women with fixed-term contracts is that the former work fewer hours per week (albeit having the same yearly earnings). However, this cannot be used as a reliable estimate of the motherhood premium because mothers are very different from childless women, as found in the subsequent rows of this table. For instance, we observe that mothers are more educated and more likely to be cohabitating than childless female workers. Looking at job differences across the two groups, mothers are more likely to work part-time than childless women. Moreover, mothers have more experience and tenure than childless women, regardless of their type of contract. Several different patterns emerge when comparing mothers and childless women in different segments of the labor market. For instance, in the primary labor market, mothers are more likely to work in the public sector and in larger firms, experience fewer months of inactivity and turnover, and are more likely to return to the same employer after a period of inactivity. In contrast, among fixed-term contract workers, mothers spend more months non-employed, experience higher turnover, and are considerably less likely to return to the same employer after a period of inactivity. These differences by type on contract suggest that

\footnotetext{
${ }^{22}$ Although one individual can appear under different categories in different waves of the panel, it should be noted that these four categories are mutually exclusive.
} 
mothers in the secondary labor market are in more vulnerable positions with more unstable employment relationships than those in the primary labor market.

Compared to other datasets, our data has several advantages. First, the CSWH is a very large sample (for instance, our sample of mothers is more than 5 times larger than that in the 1994-2001 European Household Panel). Second, the CSWH provides the complete labor market history for those women registered in the Social Security Administration in 2006, for up to 21 years. Although the restriction that information on type of contract is available reduces the length of women's earnings trajectories to up to ten years, it is still a non-negligible length of time. Third, it contains reliable information on monthly earnings, tenure, experience, and change of employer, as the information comes directly from the payroll records. Measurement error due to recall bias or self-reporting for these key variables is minimized with this data set. Similarly, non-response is not an issue. Fourth, the dataset has rich information on individual characteristics, including education, age, ethnicity, marital status, and number and age of children in the household.

One of the short-comings of the CSWH is that it contains only information on individuals working in the formal sector. While Izquierdo et al., 2010 find that, compared to the Labor Force Survey, these dataset offers an accurate picture of the formal sector in Spain, Ramos Muñoz, 2007, find that some differences exists for youth, females and foreigners due to the fact that the CSWH does not account for the informal sector. For this to be a problem in our study, we would need to argue that incidence of the informal sector is greater among mothers than childless female workers (or vice-versa), which could be plausible. Unfortunately, there is little we can do about this. That said it is important to keep in mind that the bulk of our analysis focuses on the time period 1996 through 2006, which was mainly a period of economic 
expansion, reducing the relevance of the informal sector. In addition, we study the effect of motherhood on native women, thus further reducing potential problems with informality—much more common among immigrant workers.

Another short-coming is that we lack information on non-labor income data. A robustness check would be to explore the sensitivity of the results for two subgroups of women: single women versus those cohabitating, and to find that the main findings of the paper hold across the two groups. Unfortunately, we only observe information on cohabitating as of 2006. Moreover, only 151 women with fixed-term contracts are leaving alone in 2006, which precludes us from performing any reasonable test.

\section{Methodology and Results}

\section{V.1. The Motherhood Earnings Differential}

We begin our analysis by estimating the average effect of becoming a mother on yearly earnings. Table 3 presents our estimates using a variety of approaches. For ease of the exposition, we use a simple dummy variable approach to measure the log yearly earnings difference associated with becoming a mother, conditional on controls. ${ }^{23}$ We begin by estimating the following equation using pooled OLS:

$$
L n W_{i t}=X_{i t} \beta+\theta \operatorname{CHILD}_{i t}+\phi_{i}+\psi_{j(i, t)}+\mu_{i t}
$$

Here, $L n W_{i t}$ is the natural $\log$ of real yearly earnings of individual $i$ at year $t ; X_{i t}$ is a vector of individual and job characteristics for individual $i$ at time $t$, with $\beta$ the corresponding coefficient vector (including an intercept). Because there has been much debate on whether variables that control for employer characteristics, industry, or occupation ought to be included in the specification, we present alternative

\footnotetext{
${ }^{23}$ Earnings function parameters differ between mothers and childless women, but the gaps in the earnings estimated using the dummy variable approach differ little from those based on separate equations by motherhood status, and evaluated at the means.
} 
specifications to evaluate the robustness of the results. $C H I L D_{i t}$ is a binary variable equal to one if the woman becomes mother at year $t$. The error term includes both a random component $\mu_{i t}$ with mean zero and constant variance, a worker-specific fixed effect $\phi_{i}$, and a firm-specific fixed effect, $\psi_{j(i, t)}$ - the effect of unmeasured employer characteristics. All regressions use the Huber/White estimator of variance and allow for observations not being independent within cluster-individuals.

On average, the "unadjusted" OLS estimate of the motherhood yearly earnings differential in Spain (shown in the first column of the first row of Table 3) is a 4 log points premium for mothers. The subsequent columns estimate the motherhood earnings differential adding additional controls. The inclusion of a "part-time job" control increases the premium even further to 7 log points. While this may come as a surprise (given the anecdotal and empirical evidence on the difficulties of reconciling family and work in Spain), the following column suggest that all of the motherhood earnings premium is explained by differences in experience between mothers and childless female workers-experience being higher for the former than the latter, as observed in Table 2. After controlling for experience, the motherhood earnings differential goes to zero. These findings are consistent with earlier evidence that suggest that Spanish women prefer to wait and secure a good job before engaging in motherhood (Ahn and Mira, 2001; Baizan, 2004; de la Rica and Iza, 2005; GutierrezDomenech, 2005; García Ferreira and Villanueva, 2007).

Nonetheless OLS estimates are based on a strong assumption that becoming a mother is exogenous (conditional on the included covariates). Clearly this is not the case, as discussed earlier in Section II. To deal with individual unobserved heterogeneity, we proceed to estimate the following individual fixed-effect equation, with results shown in row 2 of Table 3 : 


$$
L n W_{i t}-\overline{\operatorname{LnW_{i}}}=\left(X_{i t}-\overline{X_{i}}\right) \beta^{\prime}+\theta^{\prime}\left(C H I L D_{i t}-\overline{C H I L D_{i}}\right)+\mu_{i t}-\overline{\mu_{i}}+\psi_{j(i, t)}-\overline{\psi_{j(i)}}
$$

Notice that the estimator of interest is the coefficient, $\theta$, which is capturing becoming a mother (regardless of whether the worker changes employer or not). Comparing the OLS and FE specification, we find (as in Molina and Motuenga, 2008) that there is positive self-selection on unobservables into motherhood in Spain. Our individuallevel FE “unadjusted" specification shows that becoming a mother lowers yearly earnings by about 9 log points. Column 3 shows that two-thirds of this earnings differential is explained by the worker's part-time status, as the motherhood penalty decreases to 3.4 log points after controlling for part-time work. Once experience is included as a covariate, the gap narrows further to 2.8 log points, indicating that mothers accumulate less experience than childless women after their first child is born. Adding additional job controls reduces further the gap, albeit only by a small amount.

Even though in the previous specification we have controlled for several firm characteristics, it is still possible that the motherhood yearly earnings differential is driven by the selection of mothers into firms that pay lower wages and that the characteristics of these firms are unobserved. For example, it is possible that mothers self-select into family-friendly jobs with attributes that facilitate the conciliation of work and family but that pay lower wages. If we do not control for these job characteristics because they are unobserved, then our estimates will suffer from an omitted variable bias. To address this, we control for both individual- and firm-level heterogeneity using the following fixed-effects estimator (shown in row 3 of Table 3):

$$
L n W_{f t}-\overline{L n W_{f}}=\left(X_{f t}-\overline{X_{f i}}\right) \beta^{\prime}+\theta^{\prime}\left(\operatorname{CHILD}_{f t}-\overline{\operatorname{CHILD}}\right)+\mu_{f t}-\overline{\mu_{f}}
$$

where $L n W_{f t}$ is the natural log of real yearly earnings of employer-individual match $f$ at year $t$, and the estimator of interest is the coefficient $\theta$. In this specification, $\theta$ is capturing the effect of becoming a mother (for those workers who do not change 
employer). On average, we have 3.2 year observations for each of the 25,563 firmworker matches.

Comparing the coefficients from this specification (row 3) to those from the individual-FE specification (row 2), we observe that the former are smaller in size than the latter, corroborating our suspicion that part of the motherhood earnings differential is explained by mothers moving to lower paying firms. This is particularly striking for the "unadjusted" estimator of the motherhood earnings differential, which drops by almost half_-from minus 9 percentage points difference to minus 5 percentage points. After controlling for part-time status, we observe that the difference in the estimated motherhood gap between the two specifications is considerably reduced, implying that some of the motherhood gap is explained by mothers having to change employers to be able to work part-time. However, even for those who remain with the same employer, almost half of the motherhood earnings differential is explained by mothers' reduction in hours worked. Controlling for actual experience removes the effect on pay of any leave of absence or periods not working. We observe that controlling for actual experience narrows even further the motherhood earnings differential (regardless of whether the worker remains with the same employer or not). At the end, after controlling for firm size, occupation and industry, the difference between the individual-FE and the individual- and firm-level FE is small, suggesting that these job characteristics approximate well low versus high-paying jobs. This finding implies that the individual-FE estimator of the family gap with good quality data on job characteristics is able to control for that mothers' selection into lower paying firms. However, it is important to note that a (far from insignificant) motherhood earnings differential of 2.3 log points remains even after controlling for individual- and firmlevel observed and (time invariant) unobserved heterogeneity. To put this coefficient 
into context, becoming a mother in Spain is equivalent to a net loss in annual earnings as large as one third the gains from the returns to a year of schooling.

\section{Motherhood Earnings Differentials Before and After Birth}

To examine how the earnings differential between mothers and childless women evolve over time, Figure 2 displays estimates of the effect of motherhood on women's earnings profiles several years before and after giving birth using alternative specifications of the following equation:

$L n W_{i t}=\alpha_{0}+\beta X_{i t}+\delta_{1}$ MOTHER $_{i t}+\sum_{k=1}^{T} \theta_{k}$ CHILD $_{i t_{0}+k}+\sum_{j=1}^{T t} \varphi_{j}$ CHILD $_{i t_{0}-j}+\phi_{i}+\psi_{j(i, t)}+\mu_{i t}$

Where $\sum_{k=1}^{T} C H I L D_{i t_{0}+k}$

is a vector of dummies indicating whether the individual has had a

child the last year, for the previous two years, and so on. Similarly, is a $\sum_{j=1}^{T} C H I L D_{i t_{0}-j}$

vector of dummies indicating whether the individual will have a child in one year, in two years, and so on. For a mother who has a child in year $t_{0}$, the estimators of interest are: (i) the sum of the coefficients, $\delta_{1}+\theta_{1}$, which captures the effect of becoming a mother one year after birth; and (ii) the sum of the coefficients, $\delta_{1}+\varphi_{1}$, which captures the effect of becoming a mother one year after birth.

Equation (4) is estimated within-i deviations from worker-specific means (individual-level FE), which is essentially a similar specification as the one from Jacobson, Lalonde and Sullivan, 1993, or Hijzen, Upward, and Wright, 2008; and within- $f$ deviations from worker-firm-specific matches means (that is, individual- and firm-level FE). The coefficients of interest for each of these specifications are plotted in Panels A and B of Figure 2. As either estimation delivers similar profiles (with, as major difference, the size of the motherhood earnings' gap), the discussion is centered 
in the specification that controls for both individual- and firm-level unobserved heterogeneity.

Panel B in Figure 2 shows that, after controlling for individual- and firm-level unobserved heterogeneity, as well as socio-demographic characteristics, "mothers to be” in Spain experience important earnings increases, representing up to 6 log points, several years prior to giving birth to their first child (compared to childless women). This finding is consistent with earlier evidence that suggests that women in Spain wait to secure a good job prior to becoming mothers. An alternative explanation for mothers' higher earnings prior to giving birth is that mothers who stay in the labor force over time are those with higher productivity (relative to childless women who remain in the labor force). To explore whether participation bias could be affecting our results, we compared different waves of the CSWH, and constructed an indicator of non-participation (as we were able to identify those individuals who were present in one wave but not in the next one)_-unfortunately, given the nature of the CSWH, this was only possible after 2004. We then estimated whether there was a differential effect on earnings levels and growth for women exiting the labor force as opposed to those who stayed, paying special attention to a potential differential effect by motherhood status (shown in Table A.1). While we did find that those women who exited the labor market had lower earnings both in levels and growth compared to those who stayed in the labor force, we could not reject the null hypothesis that these differences did not varied with motherhood status, suggesting that any differences driven by (lack of) participation are wiped out in our analysis given that we always compare mothers and childless women, and implying that our estimates ought not to be seriously affected by a participation bias. 
Panel B in Figure 2 also shows that there is a, far from insignificant, earnings' dip emerging right after giving birth and lasting until the child is around 9 years old. The decrease in earnings right after birth represents almost 4 log points, reducing by more than half the "mothers to be” earnings advantage. As the children age, mothers eventually return to their earnings levels before birth. Panel B in Figure 2 also shows that about half of the motherhood dip is explained by a decrease in hours worked as mothers move into part-time work. Controlling by women's experience further reduces the mother's dip.

Our finding of a motherhood earnings dip is consistent with Becker’s 1985 and 1991 models illustrating that mothers might optimally choose to decline work and effort outside the home after their first child is born (absent a change in marginal utility of income). Alternatively, our finding is also consistent with the view that argues that this drop is likely to be explained by the employers moving mothers off the "fast track" as they, rightly or wrongly, perceive them as less committed to their jobs and less likely to rearrange work schedules to deal with immediate crises at work. Distinguishing between the first and the second interpretation is highly controversial and always difficult in this literature. However, as we will explain in the next section, our analysis of the motherhood earnings loss by type of contract suggests an important role for mothers’ decision to reduce time and effort spent outside home.

\section{V.2. The Motherhood Earnings Differential By Contract Type}

The analysis thus far has analyzed the average yearly earnings difference between mothers and childless women. However, the average effect may hide important differences across groups. In what follows, we study the motherhood yearly earnings differential by type of contract. The rationale being that the effect of motherhood on 
earnings and the channels through which it operates may well differ by the level of job protection the worker has, and whether she is in the primary labor market (with a permanent contract) or in the secondary labor market (with a fixed-term contract). For instance in Becker's models, marginal utility of income would likely also rise after birth due to the need for increased food, housing, diapers, child care, and the like (a point not emphasized by Becker). As a result, whether time or energy outside of home declines depends on the relative changes in marginal utility of income and the changes in the marginal productivity of time and energy spent in the home. This may have different consequences for women in the primary (with secure jobs) versus the secondary (with unstable jobs) labor market. Those with a permanent contract might see less of a change in the utility of income and be more inclined to cut back on time and energy devoted to market work. On the other hand, they may also be in jobs where the impact of effort on wages is greater, leading to a smaller reduction in effort. Alternatively, Elwood et al., 2010, develop a model where wages and wage growth depend on labor market experience in addition to effort. In their model the effect of children on careers is likely to differ for high- and low-skill parents because they may be in jobs that differ in their sensitivity to effort and because they might make different choices regarding their work effort upon childbearing. Such model could easily be modified to apply to women in the primary versus secondary labor market.

Panels A, and B of Table 4 presents the OLS, and individual-level FE results described in equations (5) and (6) below:

$$
L n W_{i t}=X_{i t} \beta+\delta_{1} C H I L D_{i t}+\delta_{2} \text { FIXED }_{i t_{0}-1}+\delta_{3}\left(C H I L D_{i t} x F I X E D_{i t_{0}-1}\right)+\phi_{i}+\psi_{j(i, t)}+\mu_{i t}
$$

$$
\begin{aligned}
& L n W_{i t}-\overline{\operatorname{LnW_{i}}}=\left(X_{i t}-\overline{X_{i}}\right) \beta^{\prime}+\delta_{1}{ }^{\prime}\left(\text { CHILD }_{i t}-\overline{\text { CHILD }_{i}}\right)+\delta_{2}{ }^{\prime}\left(\text { FIXED }_{i t_{0}-1}-\overline{\text { FIXED }_{i}}\right) \\
& +\delta_{3}\left(\left(\text { CHILD }_{i t} x \text { FIXED }_{i t_{0}-1}\right)-\left(\overline{\text { CHILD }_{i}} x \overline{\text { FIXED }} i\right)\right)+\mu_{i t}-\overline{\mu_{i}}+\psi_{j(i, t)}-\overline{\psi_{i}}
\end{aligned}
$$


Where FIXED ${ }_{i t_{0}-1}$ is a binary variable equal to one if the worker holds a fixed-term contract at time $t_{0}-1$. For mothers, $t_{0}$ is the year of birth of the child. Thus, we control for type of contract the year before the birth of the child. The coefficients $\delta_{1}$ and $\delta_{1}+\delta_{3}$ are shown in Table 4. That is, we focus our analysis on comparing mothers and childless women with a permanent contract $\left(\delta_{1}\right)$, and mothers and childless women with a fixed-term contract $\left(\delta_{1}+\delta_{3}\right)$. The error term includes both a random component $\mu_{i t-1}$ with mean zero and constant variance, a worker-specific fixed effect $\phi_{i}$, and a firmspecific fixed effect, $\psi_{j(i, t-1)}$. All regressions use the Huber/White estimator of variance and allow for observations not being independent within cluster-individuals.

Note that although the specifications that controlled for both individual- and firmlevel fixed effects is our preferred specification when estimates are tabulated on average for all women, this is not necessarily the case when the analysis is done by type of contract. The reason for this is that in this specification, identification takes place using those workers who do not switch employers; however remaining with the same employer is quite infrequent among fixed-term contract mothers. As shown in Table 2, mothers with fixed-term contracts doubled the number of times they changed employers compared to mothers with permanent contracts. They were also more likely to change employers than childless women with fixed-term contracts. As a consequence, individual- and firm-level FE estimators will be presented only for women working with permanent contracts in panels $\mathrm{D}$ and $\mathrm{E}$.

Because women may select into type of contract, the specifications in panel C and $\mathrm{E}$ use an instrument to correct for the potential endogeneity by type of contract. Our identification strategy relies on a set of subsidies implemented by all but two Spanish regions with the objective of promoting the conversion of fixed-term contracts into 
permanent ones (summarized in Table A.2). The subsidy amount varied with the region of residence, the year in which the contract started, and the age and gender of the worker-often being larger if the worker with a fixed-term contract was a woman younger than 30 years or older than 45 years. Overall, the amount granted ranged between $€ 1,200$ and $€ 14,000$ euros. According to García-Pérez and Rebollo-Sanz, 2009, the subsidy amount represented about $20 \%$ of the average worker's yearly labor costs. To compute our instrument, we used information on the sequence of subsidies an individual may have been eligible for during all her work life. Thus, the instrument takes into account the fact that the type of contract an individual has at time $t$ depends on the type of contract the individual had prior to $t$ (and consequently, on the whole history of subsidies she may have been eligible for up until then). This is especially relevant for those workers with a permanent contract at time $t$, as they are likely to have been eligible for a subsidy in the past that converted their fixed-term contract into a permanent one. To take this effect into account we compute our instrument as follows. First, we used the year, the age of the worker and the region of residence to assign to each worker at each point in time the monetary magnitude of the subsidy (in constant 2006 euros using regional deflators of household gross disposable income). Then, for each individual and year, we calculated the sum of subsidies for which this individual had been eligible for up until time $t$. Note that this estimate is based on each worker's complete work history, linking at each point in time the type of contract an individual has with the history of subsidies that this worker may have been eligible for up until then.

We start by examining whether the amount of the subsidy to convert a temporary contract into a permanent one is a good instrument for the prevalence of such contracts. The first-stage regression, shown in Appendix Table A.3, is a linear probability model 
estimated using pooled OLS with as LHS variable a dummy indicating whether the individual is working under a permanent contract at time $t$ regressed against the instrument and a list of covariates capturing workers' characteristics (as well as industry and occupation dummies). ${ }^{24}$ The parameter of interest is the coefficient of the Instrument, which is an intention-to-treat effect measuring the impact of the subsidy amount on the likelihood that a worker is currently working under a permanent contract. This coefficient is identified by comparing the chances of being observed with a permanent contract for two workers hired at the same time, but whose employer had access to different subsidies either because they were in different regions, or because the workers belonged to different age groups. If the subsidies to a permanent contract increased the likelihood of such type of contracts the coefficient would be statistically significant and positive, which is what we find. ${ }^{25}$

In our preferred specification, the two-stage individual-level FE estimator shown in panel C, identification takes place through women who become mothers (regardless of whether they change employers or not). The main finding is that the motherhood earnings differential found in Section V.1 is driven by women in the primary labor market (that is, those with permanent contracts). While the "unadjusted" motherhood earnings gap is 9 percentage points among women with permanent contracts, no differential is observed among women with fixed-term contracts (even after controlling for observable workers' and firms' characteristics). Among women with permanent contracts, half of the motherhood earnings differential is explained by part-time work.

\footnotetext{
${ }^{24}$ Using pooled OLS, as opposed to individual or firm FE, in the first step guarantees that we exploit the variation across regions in the amount of the subsidy. This is by far the most important source of variation in the instrument that we use here.

${ }^{25}$ Furthemore, our first-stage F statistic ( $\left.\mathrm{F}=589\right)$ accepts the alternative hypothesis of a strong instrument. The Durbin test (167.818) and the Wu-Hausman test (168.066) are much larger than 1.96 and indicate that our contract variable is endogenous and that the IV estimation is superior to the OLS estimation.
} 
Differences in accumulated experience after birth explain an additional $12 \%$ of the motherhood earnings differential.

As observed earlier in Section V.1, including part-time status as a control has a smaller effect reducing the motherhood earnings gap among women with permanent contracts when one controls for both individual- and firm-FE and corrects for endogeneity by type of contract (specification shown in panel E) than in our preferred specification (panel C). This suggests that part of the motherhood earnings differential in the primary labor market is explained by mothers changing employers when moving into part-time work. In contrast, the reduction in the motherhood earnings gap when one controls for experience is greater in panel E than panel C, suggesting that among those workers who stay with their former employer, much of the motherhood earnings gap is explained by mothers accumulating less experience, that is, taking leave of absence.

Other interesting results from Table 4 are discussed below. First, while there is positive self-selection of unobservables into motherhood in the primary labor market, the opposite is true among women with fixed-term contracts. Comparing OLS estimates from panel A with FE estimates from panel $\mathrm{B}$, we observe that, among women with permanent contracts, the "unadjusted" OLS 7.6 log points premium becomes an "unadjusted" 10.0 log points penalty once individual heterogeneity is controlled for, suggesting that there is positive self-selection into motherhood. In contrast, among women with fixed-term contracts, the "unadjusted” OLS 12.5 log points penalty decreases considerably to 3.6 log points after unobserved heterogeneity is accounted for, revealing that there is negative self-selection into motherhood among these women. Second, as expected, we find that selection bias due to endogeneity of type of contract is stronger among women with a fixed-term contract than those with 
permanent ones. As such, controlling for endogeneity by type of contract (that is comparing panels $\mathrm{B}$ and $\mathrm{C}$ ), we observe that most of the correction takes place in the secondary labor market.

Why do we only find an effect of motherhood on earnings for women working in the primary labor market? One explanation is that mothers with permanent contracts can reconcile family life and work either because they take (unpaid) leave of absence to take care of their small children or they move to part-time work if they stay with their former employer. In contrast, women with fixed-term contracts are less able to reconcile family and work through hours worked as their jobs are considerably more unstable. This evidence is consistent with findings from Fernández-Kranz and Rodríguez-Planas, 2010, that indicate that a 1999 law aiming at reconciling work and family life in Spain and giving the right to flexible and reduced work arrangements to care for dependents less than six years of age was only effective in the primary labor market as employers who do not want to offer reduced work hours to workers with fixed-term contracts only have to wait for their contract to expire to terminate the employment. It is also important to note that, although one might expect a greater motherhood penalty on earnings for women working in the secondary than in the primary labor market—as the former are in more vulnerable positions than the latter, what really matters is the changes in work behavior after the birth of the child, and those are actually somewhat greater for women in the primary labor market, especially with respect to part-time work. $^{26}$ For instance, women with permanent contracts work full-time all year much more than those with fixed-term contracts do one year prior to their first birth, $80 \%$ versus $65 \%$. However, one year after birth only $73 \%$ of mothers with a permanent contract continue to

\footnotetext{
${ }^{26}$ According to the $1999-2009$ Spanish Labor Force Survey, as few as $12.48 \%$ of women working parttime with fixed-term contracts do so to take care of the family, compared to $28.60 \%$ of women with permanent contracts who work part-time, suggesting that while part-time work may be a cultural choice among Spanish women in the primary labor market it is not the case in the secondary market.
} 
work full time, whereas the number for those with a fixed-term contract working full-time remains practically unchanged at $63 \%$. A third possibility is that wages decline in response to mothers leaving their previous employer when they give birth (either by choice or because they cannot get back their previous job). Women in the primary sector who make such a change give up any benefits they were gaining from firmspecific human capital and presumably lose their returns to tenure. Finally, it is possible that mothers are perceived (rightly or wrongly) as less willing or able to spend the extra hour that superiors may use as a signal of commitment to the enterprise, and are thus less likely to gain promotions.

\section{Motherhood Earnings Differentials Before and After Birth}

In this section, we examine how the earnings differential between mothers and childless women evolve over time and how these earnings profiles differ by type of contracts, mimicking the analysis done in Figure 2, but interacting the coefficients by a dummy indicating the contract type. Consistent with our earlier findings from Table 4, Figure 3 shows that the higher earnings for "mothers to be" and the subsequent dip observed in Figure 2 are mainly driven by women working in the primary labor market. In contrast, for women with fixed-term contracts the motherhood dip is less apparent.

Figure 3 also reveals that, for women with permanent contracts, moving to parttime work explains close to half of the motherhood gap in Panel A (and in Panel C) corroborating our earlier results that much of the motherhood dip is explained by mothers with permanent contracts changing to part-time. Most importantly, results from panel B of Figure 3 show that, a far from insignificant, motherhood dip remains among women with permanent contracts who stay with the same employer, suggesting that even when they remain in the same firm, mothers are removed off the "fast track" as employers rightly or wrongly perceive them as less committed to their jobs and less 
likely to rearrange work schedules to deal with immediate crises at work. Finally, it is worth highlighting that the earnings advantage for mothers to be is smaller among women with permanent contract than those with fixed-term contract.

\section{Conclusion}

Using rich data from Social Security records, we find that a negative motherhood earnings differential of 2.3 log points remains even after controlling for individual- and firm-level unobserved heterogeneity, as well as socio-demographic and job characteristics. We claim that this effect is far from insignificant as becoming a mother in Spain is equivalent to a net loss in annual earnings as large as one third the gains from the returns to a year of schooling. Moreover, the analysis of the earnings profile of mothers and childless women before and after birth reveals that "mothers to be" experience important earnings increases, representing up to 6 log points, several years prior to giving birth to their first child. However, we find that mothers' earnings advantage gets seriously hit right after the birth of the first child, taking up to nine years to eventually return to their pre-birth earnings levels. Methodologically, we find that, after controlling for firm size, occupation and industry, the difference between the individual-FE and the individual- and firm-level FE is small, implying that the individual-FE estimator of the family gap with good quality data on job characteristics is able to control for mothers' selection into lower paying firms.

Because of the duality of the Spanish labor market, the analysis is then done by type of contract. Three insightful results emerge. First, we find that both the "adjusted" motherhood earnings differential and the motherhood dip is driven by women with permanent contracts prior to giving birth. For these women, about half of the earnings losses occur because mothers change employers to work part-time, or (if 
they stay with their former employer) they take leave of absence. Second, we find that while there is positive self-selection into motherhood in the primary labor market, the opposite is true among women with fixed-term contracts. Finally, we find that endogeneity by type of contract mainly affects women in the secondary labor market.

Our paper contributes to the literature that hints to institutional differences, as well as, differences in policies aiming at reconciling family and work as possible explanations behind the wage differences observed between mothers and childless women (see for instance, Blossfeld, 1997; Davies and Pierre, 2005; and Gangl and Ziefle, 2009). Indeed, our results find that most of the motherhood dip is driven by workers in the primary labor market, suggesting that mothers use the leeway granted by job protection in Spain to trade off wages for more family friendly work arrangements, suggesting that work-family conciliation comes at a wage cost. Moreover, our findings also reveal that mothers not benefitting from job protection might not even have the choice of balancing work and life at a wage cut cost. Future research ought to investigate the possibilities of family and work conciliation in a segmented labor market, such as the Spanish one. Finally, the results in this paper inform us that whatever policies are currently in place in Spain to reconcile family and work, they are clearly not sufficient. Other policies (such as raising the availability of affordable goodquality childcare) ought to be used to help women turn to full-time jobs with more prospects. 


\section{REFERENCES}

Ahn, N. and P. Mira. 2001. “Job Bust, Baby Bust?: Evidence from Spain” Journal of Population Economics, vol. 14, pp. 505-521.

Albrecht, J.W., Edin, P-A., Sundstrom, M., \& Broman, S.B. 1999. "Career Interruptions and Subsequent Earnings: a Re-examination using Swedish Data.” Journal of Human Resources, 34, 294-311.

Amuedo-Dorantes, C. 2000. "Work Transitions Into and Out of Involuntary Employment in a Segmented Market: Evidence from Spain,” Industrial Labor Relations Review, 2000, 53(2): 309-325.

Amuedo-Dorantes, C. and J. Kimmel. 2005. “The Motherhood Wage Gap for Women in the United States: The Importance of College and Fertility Delay." Review of Economics of the Household, 3(1):17-48.

Anderson, D. J., M. Binder, and K. Krause. 2003. "The Motherhood Wage Penalty Revisited: Experience, Heterogeneity, Work Effort and Work-Schedule Flexibility” Industrial and Labor Relations Review. Vol. 56, No. 2 (January), pp. 273-294.

. 2002. “The Motherhood Wage Gap: Who Pays it and Why?” American

Economic Review Papers and Proceedings, Vol. 92, No. 3 (May), pp. 354-58.

Angrist, J. and W. Evans. 1998. “Children and Their Parents' Labor Supply: Evidence from Exogenous Variation in Family Size,” American Economic Review, v. 88: 450-477.

Argimón, I., and C. González. 2006. "La Muestra Continua de Vidas Laborales de la Seguridad Social.” Boletín Económico, Banco de España, (May): 39-53.

Atrostic, B.K. 1982. "The Demand for Leisure and Nonpecuniary Job Characteristics," The American Economic Review, Vol. 72, No. 3 (June), pp. 428-440.

Baizán Muñoz, P. 2009. "Regional child care availability and fertility decisions in Spain.” Demographic Research 21(27): 803-842

Barceló C. and E. Villanueva, 2010. "The response of household wealth to the risk of losing the job: evidence from differences in firing costs.” Banco de España Working Paper no. 1002.

Beblo M., S. Bender, and E. Wolf. 2009. "Establishment-Level Wage Effects of Entering Motherhood.” Oxford Economic Papers, 61, 2009, 11-34.

Becker, G. 1985. "Human Capital, Effort, and the Sexual Division of Labor.” Journal of Labor Economics, 3(1), pt.2, pp. S34-S58.

. 1991. "A Treatise on the Family" (Enlarged Edition). Cambridge, MA: Harvard University Press. 
Beninger. D. 2005. “Emploi et social en France: Description et evaluation.” ZEW Documentation 03-05, Mannheim, ZEW.

Bentolila, S. and J. Dolado. 1994. "Labour Flexibility and Wages: Lessons from Spain.” Economic Policy 18: 53-99.

Bentolila S. J. J. Dolado, and J.F. Jimeno. 2008. “Two-Tier Employment Protection Reforms: The Spanish Experience.” CESifo DICE Report 4/2008.

Blanchard O. and A. Landier. 2002. "The Perverse Effects of Partial Labor Market Reform: Fixed Duration Contracts in France.” NBER Working Paper 8219, Cambridge, NBER.

Blackburn, McKinley L., David E. Bloom, and David Neumark. 1990. "Fertility Timing, Wages and Human Capital.” NBER Working Paper No. 3422, August.

Blossfeld HP. 1997. Women's part-time employment and the family cycle: a crossnational comparison. See Blossfeld\&Hakim, pp. 315-24

Bound J., C. Brown, G. Duncan; and W. Rodgers. 1989. "News in the Noise: New Evidence on the Valididty of Survey Data on Earnings.” Unpublised manuscript. Ann Arbor: University of Michigan.

. 1994. "Evidence on the Validity of Cross-Sectional and Longitudinal Labor Market Data,” Journal of Labor Economics 12, 345-368.

Bound, John, C. Brown, and N. Mathiowetz. 2001. "Measurement Error in Survey Data." In Handbook of econometrics, vol. 5, ed. James Heckman and Ed Leamer, 3705-3843. Amsterdam: North-Holland.

Bound, J., and A. Krueger, "The Extent of Measurement Error in Longitudinal Earnings Data: Do TwoWrongs Make a Right?,” Journal of Labor Economics, 9 (1991), 124.

Bover, O., and R. Gómez. 2004. “Another Look at Unemployment Duration:

Exit to a Permanent Job vs. a Temporary Job,” Investigaciones Economicas, 28(2): 285314.

Bronars, Stephen and Jeff Grogger, "The Economic Consequences of Unwed Motherhood: Using Twin Births as a Natural Experiment," American Economic Review, v. 84 (1994): 1141-1156.

Brownstone, David \& Valletta, Robert G, 1996. "Modeling Earnings Measurement Error: A Multiple Imputation Approach," The Review of Economics and Statistics, MIT Press, vol. 78(4), pages 705-17.

Budig, Michelle J. and Paula England. 2001. “The Wage Penalty for Motherhood," American Sociological Review, Vol. 66, (April), pp. 204-225. 
Cahuc P. and F. Kramarz. 2004. "De la Précarité à la Mobilité: Vers une Sécurité Sociale Professionnelle.” Rapport au Ministre d'Etat, Ministre de l'Economie, des Finances et de l'Industrie et au Ministre de l'Emploi, du Travail et de la Cohésion Sociale, Paris.

Cherlin, Andrew J. 2001. "New Developments in the Study of Nonmarital Childbearing." in Out of Wedlock. Causes and Consequences of Non-Marital Fertility. Ed. Lawrence L. Wu and Barbara Wolfe, 143-172. New York: Russell Sage Foundation.

Connolly, S. and M. Gregory. 2009. "The Part-Time Pay Penalty: Earnings Trajectories of British Women.” Oxford Economic Papers, vol. 61 no. S1 : 76-97.

Cristia, J. P. 2008. "The Effect of a First Child on Female Labor Supply: Evidence from Women Seeking Fertility Services." Journal of Human Resources, 43(3): 487510.

Datta Gupta, Nabanitta and Nina Smith. 2002. “Children and Carrer interruptions: The Family Gap in Denmark.” Economica, 69, pp. 609-629

Davies, Rhys and Gaelle Pierre. 2005. "The Family Gap in Pay in Europe: A CrossCountry Study." Labour Economics, 12:469-486.

De la Rica, S. 2004. "Wage Gaps between Workers with Indefinite and Fixed-Term Contracts: The Impact of Firm and Occupational Segregation." Moneda y Crédito 219: 43-69.

De la Rica S., and M.D. Ferrero. 2003. "The Effect of Fertility on Labour Force Participation: the Spanish Evidence.” Spanish Economic Review, vol 5 (2).

De la Rica, S., and Iza. 2005 "Career Planning in Spain: Do Fixed-Term Contracts Delay Marriage and Parenthood?” Review of Economics of the Household 3, pp.4973.

Desai, S. and L.J. Waite. 1991. "Women’s Employment During Pregnancy and After the First Birth: Occupational Characteristics and Work Commitment." American Sociological Review. 56:551-66.

Dolado, J., C. García-Serrano and J.F. Jimeno. 2002. "Drawing Lessons from the Boom of Temporary Jobs in Spain,” Economic Journal, 112(480): F270-295.

Dolado, J.; M. Jansen, and J.F. Jimeno. 2007. "A Positive Analysis of Targeted Employment Protection Legislation," The B.E. Journal of Macroeconomics: Vol. 7 : Iss. 1 (Topics), Article 14.

Drobnic, S., H.-P. Blossfeld, and G. Rohwer. 1999. "Dynamics of Women's Employment Patterns Over the Family Life Course: A Comparison of the United States and Germany.” Journal of Marriage and the Family. 61:133-46. 
Duncan, G., and D. Hill. 1985. "An Investigation of the Extent and Consequences of Measurement Error in Labor-Economic Survey Data." Journal of Labor Economics, 3, no. 4: 508-32.

Edwards, M.E. 2005. "Occupational structure and the employment of American mothers of young children.” Journal of Family and Economic Issues, 26, 31-53.

Eichhorst, W. 2007. “The Gradual Transformation of Continental European Labor Markets: France and Germany Compared.” IZA Discussion Paper 2675.

Ellwood, D., L., Batchelder, and E. T. Wilde. 2010. “The Mommy Track Divides: The Impact of Childbearing on Wages of Women of Differing Skill Levels.” NBER Working Paper No. 16582.

Esping-Andersen, G., Guëll, M., and S. Brodmann. 2007. "Joint Household Fertility Decisions in Denmark and Spain.” In: Esping-Andersen, Gøsta (ed.). Fertility and Family Formation in Contemporary Europe. Madrid: Fundación BBVA

Fernández-Kranz, D., and N. Rodríguez-Planas. 2010. “The Part-Time Penalty in a Segmented Labor Market.” IZA working paper No. 4342.

Fernández-Kranz, D., and A. Lacuesta. 2009. “Mothers’ Quest for Job Protection: Building the Nest or Breaking the Glass Ceiling? Evidence Using Spanish Longitudinal Data.” IE Business School Working Paper.

Galdón-Sánchez, and M. Güell. 2003. “Dismissal Conflicts and Unemployment.” European Economic Review, 47 (2): 127-139.

Gangl M., and A. Ziefle. “Motherhood, Labor Force Behaviour and Women's Careers: An Empirical Assessment of the Wage Penalty for Motherhood in Britain, Germany and the US.” Demography, volume 46, number 2, 341-369.

García-Ferreira M. and E. Villanueva, 2007. "Employment Risk and Household Formation: Evidence from firing costs.” Working Paper no 737, Banco de España.

García-Pérez, J. I. and Y. Rebollo-Sanz, 2009. “The Use of Permanent Contracts Across Spanish Regions: Do RegionalWage SubsidiesWork?” Investigaciones Económicas, 33, pp. 39-68.

Gauthier, A. 2000. "Public Policies Affecting Fertility and Families in Europe: A Survey of the 15 Member States”, Paper prepared for the European Observatory on Family Matters Annual Seminar, 15-16 September 2000. [Online]. Available: http://europa.eu.int/comm/employment_social/family/observatory/downloads/sevilla _2000_gauthier.pdf.

Geronimus, A., and S. Korenman. 1992. "The Socioeconomic Consequences of Teen Childbearing Reconsidered.” Quarterly Journal of Economics, 107 (4): 1187-1214.

Güell, M. and B. Petrongolo. 2007. "How Binding are Legal Limits?: Transitions from Temporary to Permanent Work in Spain”, Labour Economics 14, 153-183. 
Gutiérrez-Doménech M. 2005. “Employment Transitions After Motherhood in Spain”, Labour Special Issue, 19(0), 123-148.

Hernanz, V. 2002. "El Trabajo Temporal y la Segmentación: Un Estudio de las Transiciones Laborales.” Unpublished PhD Dissertation, Universidad de Alcalá de Henares, Madrid.

Herrarte, A., J. Moral-Carcedo, F. Sáez. 2007. "The Effect of Fertility on the Decision of Abandoning the Labour Market: The Case of Spain," Working Papers in Economic Theory 2007/11, Universidad Autónoma de Madrid.

Hijzen A. and P. Wright. 2010. “The income losses of displaced workers”. Journal of Human Resources 45(1) pp.243-269 .

Hoffman, S. 1998. “Teenage Childbearing Is Not So Bad After All...Or Is It? A Review of the New Literature.” Family Planning Perspectives, 30(5): 236-239.

Hotz, V. J., S. Williams McElroy, and S. G. Sanders. 1997. “The Impacts of Teenage Childbearing on the Mothers and the Consequences of Those Impacts for Government.” in Kids Having Kids: Economic Costs and Social Consequences, ed. Rebecca A. Maynard. Washington, D.C.: Urban Institute Press.

Hotz, V. J., S. Williams McElroy, and S. G. Sanders. 2005. "Teen Childbearing and Its Life Cycle Consequences.” Journal of Human Resources, 45(3): 683-715.

Izquierdo, M., and Lacuesta, A. 2007. "Wage Inequality in Spain: Recent Developments.” Banco de España Research Paper No. 0615; ECB Working Paper No. 781.

Jacobs, S.C. 1997. "Employment Changes Over Childbirth: A Retrospective View." Sociology. 31:577-90.

Joshi, H., P. Paci and J. Waldfogel, 1999. "The Wages of Motherhood: Better or Worse?” Cambridge Journal of Economics, 23(5), pp. 543-64.

Korenman, S., and Neumark, D. 1992. "Marriage, motherhood, and wages” Journal of Human Resources, 27, 233-255.

Korenman, S., and Neumark, D. 1994. "Sources of Bias in Women's Wage Equations: Results Using Sibling Data.” The Journal of Human Resources, Vol. 29, No. 2, 379-405.

Kunze, A., and Ejrnaes, M. 2004. "Wage dips and drops around first birth.” IZA Discussion Papers 1011, Institute for the Study of Labor, Bonn (Germany)..

Louis S. Jacobson, Robert J. LaLonde, Daniel G. Sullivan. "Earnings Losses of Displaced Workers.” The American Economic Review, Vol. 83, No. 4 (Sep., 1993), pp. 685-709. 
Lundberg, S. and E. Rose. 2000. "Parenthood and the Earnings of Married Men and Women.” Labour Economics, 7(6), pp.689-710.

Jimeno, J.F. and L. Toharia. 1993. “The Effects of Fixed-Term Employment on Wages: Theory and Evidence from Spain,” Investigaciones Económicas, 17(3): 475-494.

Loughren, D., and J. Zissimopoulos. 2008. "Why Wait? The Effect of Marriage and Childbearing on the Wages of Men and Women." Working Paper, RAND Corporation, Santa Monica, CA.

Molina J., and V. Montuenga, 2009. "The Motherhood Wage Penalty in Spain," Journal of Family and Economic Issues, Springer, vol. 30(3), pages 237-251, September.

Kunze, A. 2002. "The Timing of Working Career and Depreciation of Human Capital.” IZA Discussion Paper No. 509, May 2002.

Mertens, N., Van Doorne-Huiskes, A., Schippers, J., Siegers, J., 1999. "Women’s wage rate and the timing of children.” The Netherlands' Journal of Sociology, 61- 77.

Miller, A. 2008. “The Effects of Motherhood Timing on Career Path.” Working Paper, Department of Economics, University of Virginia.

Nielsen, H., M. Simonsen, and M. Verner. 2004. "Does the Gap in Family-Friendly Policies Drive the Family Gap?” Scandinavian Journal of Economics, Vol. 106, No. 4 (December), pp. 721-44.

OECD, 2001. Balancing Work and Family Life: Helping Parents into Paid Employment. OECD Employment Outlook.

OECD. 2002. "Women at Work: Who Are They and How Are They Faring?" Employment Outlook, 63-125.

Phipps, S., P. Burton and L. Lethbridge. 2001. "In and out of Labour Market: Longterm Income Consequences of Child-Related Interruptions to Women's Paid Work.” Canadian Journal of Economics, 34(2), pp. 411-429.

Pischke, J., 1995. "Measurement Error and Earnings Dynamics: Some Estimates from the PSID Validation Study," Journal of Business \& Economic Statistics, American Statistical Association, vol. 13(3), pages 305-14, July.

Rosholm, M., and Smith, N. 1996. "The Danish gender wage gap in the 1980s: a panel data study.” Oxford Economic Papers, 48, 254-79.

Rosenzweig M. and K. Wolpin. 1980. "Life-Cycle Labor Supply and Fertility: Causal Inferences from Household Models." Journal of Political Economy. 
Sánchez-Mangas, R. and Sánchez-Marcos, V. 2008. "Balancing Family and Work: the Effect of Cash Benefits for Working Mothers”, Labour Economics, 15 (6), 11271142.

Segura, J. F. Durán, L. Toharia and S. Bentolila. 1991. “Análisis de la Contratación Temporal en Espanta.” Centro de Publicaciones, Ministerio de Trabajo y Seguridad Social

Shapiro and Mott. 1994. 'Long-Term Employment and Earnings of Women in relation to Employment Behaviour Surrounding First Birth.' Journal of Human Resources, Volume 26, Number 2, Spring, pp.248-275.

Taniguchi, Hiromi. 1999. “The Timing of Childbearing and Women's Wages,” Journal of Marriage and the Family, Vol. 61 (November), pp. 1008-1019.

Tietze, W. \& Cryer, D. 1999. Current trends in European early child care and education. The Annals of the American Academy of Political and Social Science, 563, 175193.

Todd, Erin L. 2001. "Educational Attainment and Family Gaps in Women's Wages: Evidence from Five Industrialized Countries," Luxembourg Income Study Working Paper No. 246, January.

Waldfogel, J. 1995. “The price of motherhood: family status and women's pay in a young British cohort.” Oxford Economic Papers, 47, 584-610.

Waldfogel, Jane. 1997. “The Effects of Children on Women's Wages," American Sociological Review, Vol. 62, pp. 209-217.

. 1998a. "The Family Gap for Young Women in the United States and Britain: Can Maternity Leave Make a Difference?” Journal of Labor Economics, Vol. 16, pp. 505-545.

1998b. - Understanding the "Family Gap" in Pay for Women With Children.|| The Journal of Economic Perspectives, 12 (1): 137-156.

Ziefle, A. 2004. "Die individuellen Kosten des Erziehungsurlaubs: Eine empirische Analyse der kurzund längerfristigen Folgen für den Karriereverlauf von Frauen" [The individual costs of parental leave: An empirical analysis of short- and longerrun consequences for women's careers]. Kölner Zeitschrift für Soziologie und Sozialpsychologie 56:213-31. 
Table 1

Incidence of Female Fixed-Term and Part-Time Employment, OECD 2008

\begin{tabular}{|l|c|c|}
\hline & $\begin{array}{c}\text { Incidence of female } \\
\text { temporary employment }\end{array}$ & $\begin{array}{c}\text { Incidence of female PT } \\
\text { employment }\end{array}$ \\
\hline Australia & $5.9 \%$ & $37.7 \%$ \\
\hline Belgium & $9.7 \%$ & $33.8 \%$ \\
\hline Germany & $14.9 \%$ & $38.6 \%$ \\
\hline The Netherlands & $20 \%$ & $59.9 \%$ \\
\hline Norway & $11.1 \%$ & $30.8 \%$ \\
\hline Spain & $\mathbf{3 1 . 2 \%}$ & $\mathbf{2 1 . 1 \%}$ \\
\hline The United Kingdom & $6 \%$ & $37.7 \%$ \\
\hline The United States & $4.2 \%$ & $17.8 \%$ \\
\hline
\end{tabular}

Figure 1

Age of Mother at the Birth of the First Child and Fertility Rate

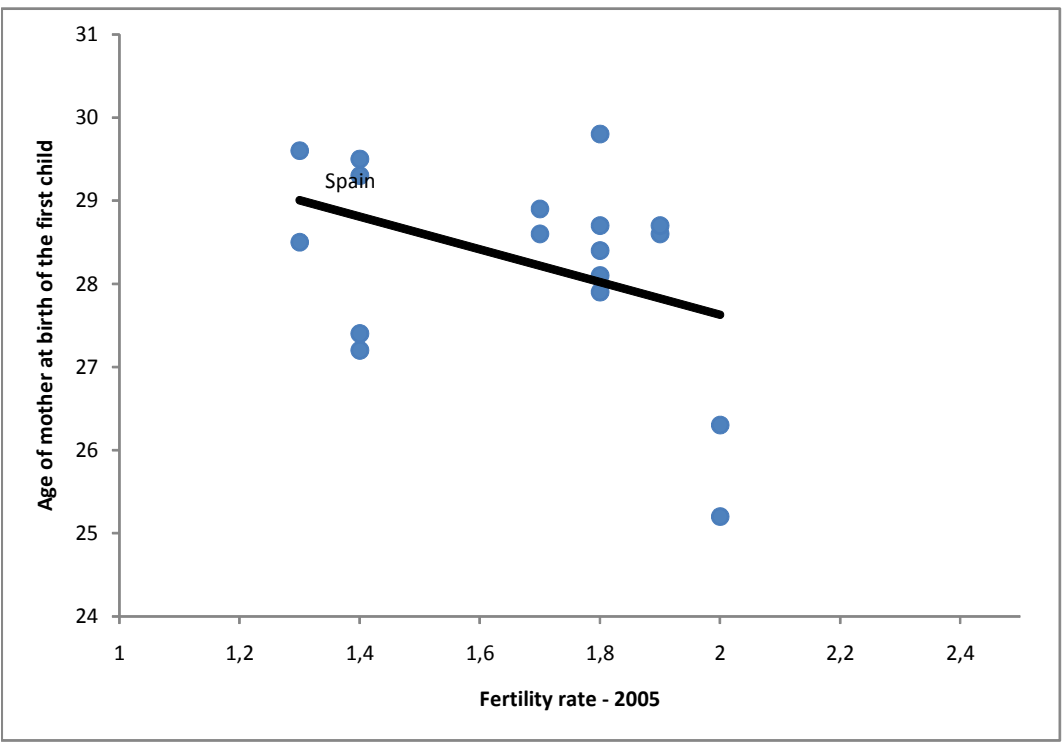

Source: UNECE Statistical Division Database, compiled from national and international (EUROSTAT, UN Statistics Division Demographic Yearbook, WHO European health for all database and UNICEF TransMONEE). The total fertility rate is the average number of children that would be born alive per woman if all women lived to the end of their childbearing years and bore children according to the age-specific fertility rates of a given year. Countries are: Austria, Denmark, Finland, France, Germany, Greece, Iceland, Ireland, Luxembourg, Netherlands, Norway, Portugal, Spain, Sweden, Switzerland, United Kingdom, United States. 
Table 2

Descriptive Statistics as of 2006*, Women, 2006 CSWH

(Percentage except where noted)

\begin{tabular}{|c|c|c|c|c|}
\hline & \multicolumn{2}{|c|}{ Permanent contract in 2006* } & \multicolumn{2}{|c|}{ Fixed-term contract in $2006^{*}$} \\
\hline \multirow{3}{*}{$\begin{array}{l}\text { Mean Log of yearly earnings } \\
\text { (cents of } € \text { ) }\end{array}$} & Mothers & Childless & Mothers & Childless \\
\hline & 14.09 & $14.03 \dagger$ & 13.91 & 13.91 \\
\hline & $(0.47)$ & $(0.56)$ & $(0.60)$ & $(0.65)$ \\
\hline \multirow[t]{2}{*}{ Mean usual weekly hours } & 35.04 & $35.81 \dagger$ & 33.34 & $34.12 \dagger$ \\
\hline & $(8.36)$ & $(8.58)$ & (10.39) & $(10.25)$ \\
\hline Age 35 to 39 years old & 63.82 & $60.77 \dagger$ & 68.38 & $56.02 \dagger$ \\
\hline Age 40 to 45 years old & 34.05 & $35.98 \dagger$ & 26.93 & $33,78 \dagger$ \\
\hline Cohabiting & 83.99 & $70.53 \dagger$ & 82.30 & $71.85 \dagger$ \\
\hline Children younger than 3 years & 24.91 & $0.00 \dagger$ & 27.99 & $0.00 \dagger$ \\
\hline Children 3 years old & 12.40 & $0.00 \dagger$ & 16.67 & $0.00 \dagger$ \\
\hline Children 4 to 6 years old & 26.10 & $0.00 \dagger$ & 29.80 & $0.00 \dagger$ \\
\hline Children older than 6 years & 36.60 & $0.00 \dagger$ & 27.53 & $0.00 \dagger$ \\
\hline High-school dropout & 38.97 & $43.24 \dagger$ & 48.11 & $51.62 \dagger$ \\
\hline High-school graduate & 51.07 & $45.74 \dagger$ & 41.45 & 38.96 \\
\hline College graduate or above & 9.96 & 11.02 & 10.44 & 9.42 \\
\hline Working part-time & 30.66 & $23.20 \dagger$ & 33.74 & $29.12 \dagger$ \\
\hline \multirow[t]{2}{*}{ Mean years of experience } & 12.90 & $9.36 \dagger$ & 7.06 & $4.06 \dagger$ \\
\hline & (5.73) & $(5.66)$ & $(4.76)$ & (3.89) \\
\hline \multirow[t]{2}{*}{ Years of experience in FT jobs } & 9.25 & $7.56 \dagger$ & 4.41 & 2.64 \\
\hline & $(7.890)$ & $(6.492)$ & $(5.007)$ & $(3.584)$ \\
\hline \multirow[t]{2}{*}{ Years of experience in PT jobs } & 3.65 & $1.80 \dagger$ & 2.65 & $1.41 \dagger$ \\
\hline & (6.104) & $(4.058)$ & $(4.507)$ & $(3.006)$ \\
\hline \multirow[t]{2}{*}{ Mean years of tenure } & 9.00 & $6.32 \dagger$ & 2.60 & $1.71 \dagger$ \\
\hline & $(6.51)$ & $(5.60)$ & $(3.51)$ & $(2.53)$ \\
\hline Public servant & 5.75 & $3.70 \dagger$ & 9.08 & 7.61 \\
\hline Mean firm size (number of & 564.50 & $417.19 \dagger$ & 494.05 & 441.99 \\
\hline workers) & $(2197.26)$ & $(1735.31)$ & $(1563.98)$ & (1425.18) \\
\hline White Collar & 14.18 & 13.62 & 14.07 & 13.10 \\
\hline \multirow[t]{2}{*}{ Months of inactivity } & 14.84 & $17.72 \dagger$ & 46.17 & $38.01 \dagger$ \\
\hline & $(19.660)$ & $(21.383)$ & (30.644) & $(29.755)$ \\
\hline \multirow[t]{2}{*}{ Times changed employer } & .83 & $1.027 \dagger$ & 1.615 & $1.360 \dagger$ \\
\hline & $(1.420)$ & $(1.571)$ & $(2.067)$ & $(2.000)$ \\
\hline \multirow{2}{*}{$\begin{array}{l}\text { Returns to same employer after } \\
\text { inactivity }\end{array}$} & 25.00 & $8.98 \dagger$ & 13.76 & $21.29 \dagger$ \\
\hline & $(.073)$ & $(.287)$ & (34.582) & $(40.976)$ \\
\hline Number of individuals & 1,686 & 5,111 & 661 & 3,588 \\
\hline
\end{tabular}

Note.- $* 2006$ or the last year a woman is observed working. In $86 \%$ of the cases, the last year observed working is 2006. The numbers in parenthesis are standard deviations. All hourly wages are deflated by the gross domestic product (GDP) deflator (base year $=2006$ ). † childless' mean significantly different from mothers' mean at the $90 \%$ confidence level. 
Table 3

Effect of Motherhood on Yearly Earnings, Different methodologies

Dependent variable: Ln(real yearly earnings)

RHS variable defining motherhood: Dummy for having one child during sample period

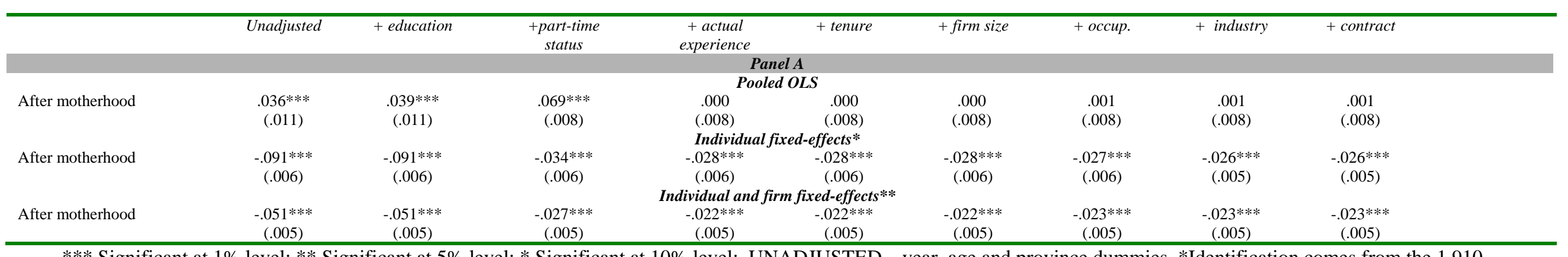

*** Significant at $1 \%$ level; ** Significant at 5\% level; * Significant at $10 \%$ level;. UNADJUSTED - year, age and province dummies. *Identification comes from the 1,910

females observed working before and after the birth of the first child. ** Identification comes from the 1,583 individual-firm matches in which the female worker is observed working before and after the birth of the first child. 
Figure 3

Motherhood Earnings Gap Over-Time

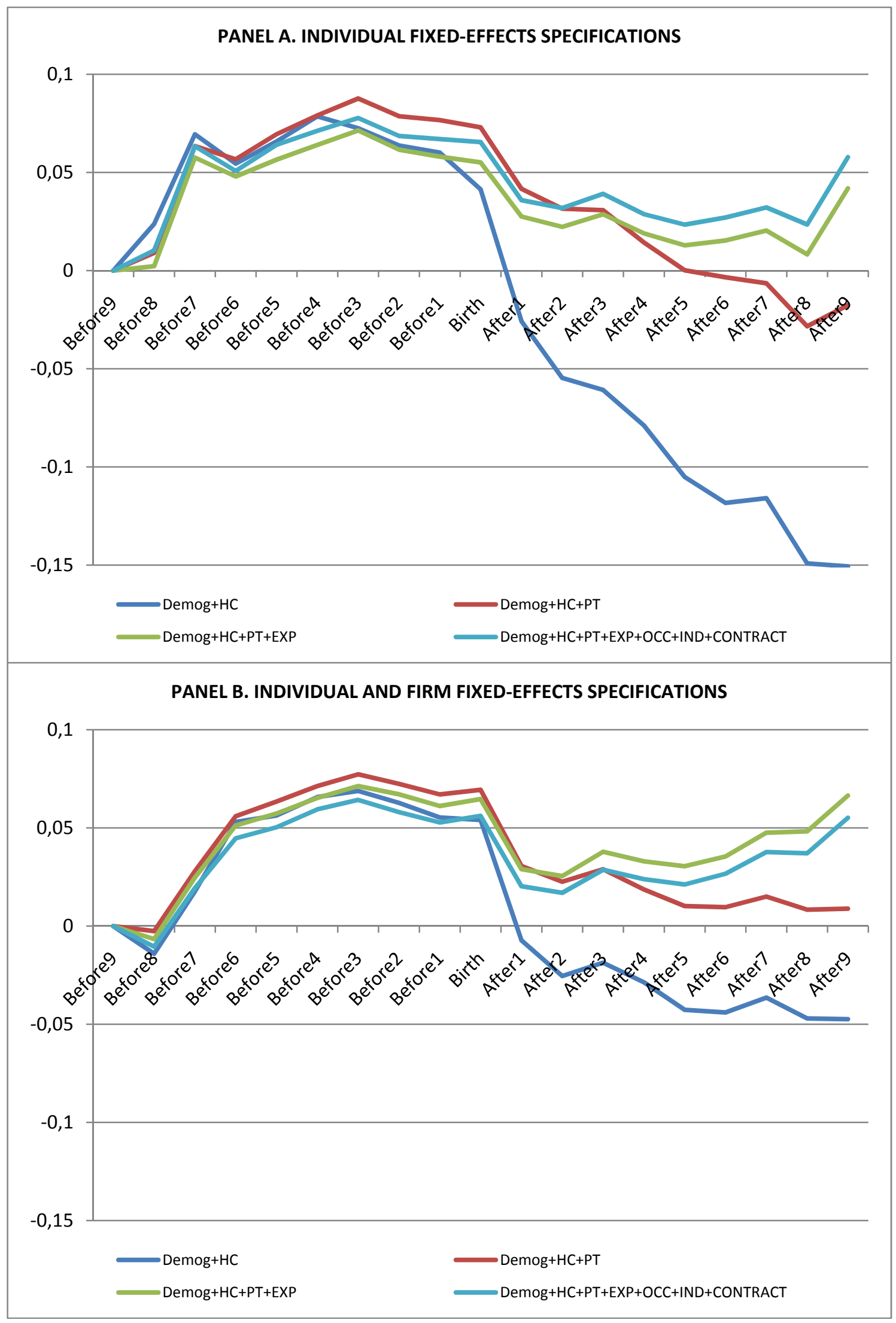


Table 4

Effect of Motherhood on Yearly Earnings, By Type of Contract, Different methodologies

Dependent variable: Ln(real yearly earnings)

RHS variable defining motherhood: Dummy for having one child during sample period

\begin{tabular}{|c|c|c|c|c|c|c|c|c|}
\hline & Unadjusted & + education & $\begin{array}{c}+ \text { part-time } \\
\text { status }\end{array}$ & $\begin{array}{c}+ \text { actual } \\
\text { experience }\end{array}$ & + tenure & + firm size & + оссир. & + industry \\
\hline \multicolumn{9}{|c|}{ EQUATION 1} \\
\hline \multicolumn{9}{|c|}{ Panel A : Pooled OLS } \\
\hline After motherhood with & $.076^{* * *}$ & $.076^{* * *}$ & $.061^{* * *}$ & .004 & .001 & .000 & .001 & -.003 \\
\hline permanent & $(.012)$ & $(.011)$ & $(.009)$ & $(.009)$ & $(.009)$ & (.009) & $(.008)$ & (.008) \\
\hline After motherhood with & $-.125^{* * *}{ }^{\dagger}$ & $-.114^{* * *}{ }^{\dagger}$ & $.016^{\dagger}$ & -.008 & -.004 & -.004 & -.000 & .002 \\
\hline fixed-term & $(.020)$ & $(.019)$ & $(.012)$ & $(.012)$ & $(.012)$ & $(.012)$ & $(.011)$ & $(.011)$ \\
\hline \multicolumn{9}{|c|}{ Panel B : Individual fixed-effects* } \\
\hline After motherhood with & $-.109 * * *$ & $-.109 * * *$ & $-.036 * * *$ & $-.035^{* * *}$ & $-.035^{* * *}$ & $-.034 * * *$ & $-.034 * * *$ & $-.033 * * *$ \\
\hline permanent & $(.008)$ & $(.008)$ & $(.006)$ & $(.006)$ & $(.006)$ & $(.006)$ & $(.006)$ & $(.006)$ \\
\hline After motherhood with & $-.036 * * *{ }^{\dagger}$ & $-.036 * * *{ }^{\dagger}$ & $-.025 * * *$ & $-.020 * *$ & $-.020^{* *}$ & $-.020^{* *}$ & $-.018 * *$ & $-.018^{* *}$ \\
\hline fixed-term & $(.011)$ & $(.011)$ & (.009) & $(.009)$ & $(.009)$ & $(.009)$ & $(.009)$ & $(.009)$ \\
\hline \multicolumn{9}{|c|}{ Panel $C: I V$ with individual fixed-effects - IV to correct for endogeneity by type of contract } \\
\hline After motherhood with & $-.090 * * *$ & $-.090 * * *$ & $-.045^{* * *}$ & $-.034 * * *$ & $-.035^{* * *}$ & $-.035^{* * *}$ & $-.036 * * *$ & $-.034 * * *$ \\
\hline permanent & $(.010)$ & $(.015)$ & $(.009)$ & $(.009)$ & $(.009)$ & $(.009)$ & $(.009)$ & $(.009)$ \\
\hline After motherhood with & $-.013^{\dagger}$ & $-.013^{\dagger}$ & $.007^{\dagger}$ & -.022 & -.021 & -.023 & -.021 & -.021 \\
\hline fixed-term & $(.015)$ & $(.015)$ & $(.013)$ & $(.016)$ & $(.016)$ & $(.016)$ & $(.016)$ & $(.016)$ \\
\hline \multicolumn{9}{|c|}{ Panel D : Individual and firm fixed-effects** } \\
\hline After motherhood with & $-.060^{* * *}$ & $-.060 * * *$ & $-.031 * * *$ & $-.026 * * *$ & $-.027 * * *$ & $-.027 * * *$ & $-.027 * * *$ & $-.027 * * *$ \\
\hline permanent & $(.006)$ & $(.006)$ & $(.005)$ & $(.005)$ & $(.005)$ & $(.005)$ & $(.005)$ & $(.005)$ \\
\hline \multicolumn{9}{|c|}{ Panel E : IV with individual and firm fixed-effects - IV to correct for endogeneity by type of contract } \\
\hline After motherhood with & $-.046^{* * *}$ & $-.046 * * *$ & $-.041 * * *$ & $-.025^{* * *}$ & $-.026^{* * *}$ & $-.025 * * *$ & $-.026 * * *$ & $-.024 * * *$ \\
\hline permanent & $(.008)$ & $(.008)$ & $(.008)$ & $(.008)$ & $(.008)$ & $(.008)$ & $(.008)$ & $(.008)$ \\
\hline
\end{tabular}

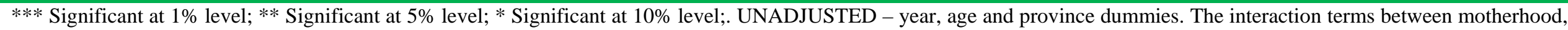

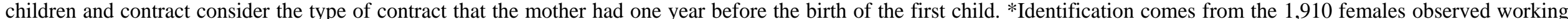

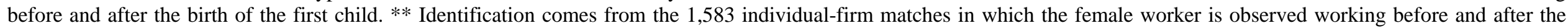
birth of the first child. Indicates that the difference between the coefficients for permanent and fixed-term contract is statistically significant at the $5 \%$ confidence level. 
Figure 4

Motherhood Earnings Gap Over-Time, by Type of Contract

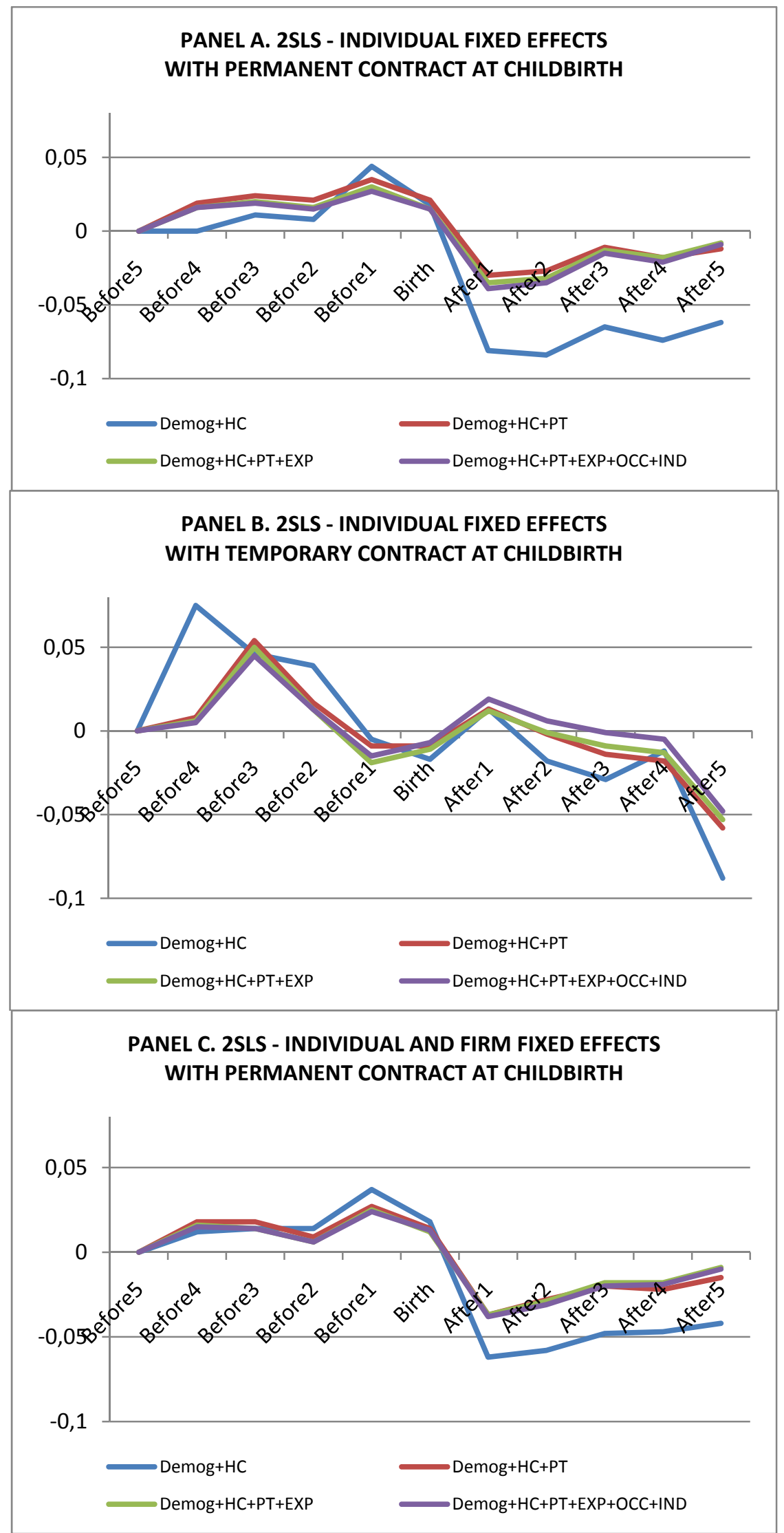




\section{APPENDIX OF THE ARTICLE:}

\section{CHUTTES AND LADDERS \\ DUAL TRACKS AND THE MOTHERHOOD DIP}

(not for publication) 
Table A.1

Effect Mobility Coefficient from Yearly Earnings Regression

Dependent variable: Ln(real yearly earnings 2006) and Wage growth 2004-2006

RHS variable out of the labour force in 2007 interacted with other variables

\begin{tabular}{|c|c|c|c|c|}
\hline & \multicolumn{2}{|c|}{ Wage in levels 2006} & \multicolumn{2}{|c|}{ Wage growth 2004-2006 } \\
\hline & Unadjusted & $\begin{array}{c}+ \text { All } \\
\text { covariates }\end{array}$ & Unadjusted & $\begin{array}{c}+ \text { All } \\
\text { covariates }\end{array}$ \\
\hline Permanent & $\begin{array}{c}.022 * * * \\
(.003)\end{array}$ & $\begin{array}{c}-.021 * * * \\
(.003)\end{array}$ & $\begin{array}{c}-.030 * * * \\
(.004)\end{array}$ & $\begin{array}{c}.001 \\
(.004)\end{array}$ \\
\hline Mother & $\begin{array}{c}-.107 * * * \\
(.009)\end{array}$ & $\begin{array}{c}-.015 * * * \\
(.007)\end{array}$ & $\begin{array}{c}-.079 * * * \\
(.010)\end{array}$ & $\begin{array}{c}-.035^{* * *} \\
(.010)\end{array}$ \\
\hline Mother Permanent & $\begin{array}{c}.069 * * * \\
(.011)\end{array}$ & $\begin{array}{c}.025 * * * \\
(.008)\end{array}$ & $\begin{array}{c}.007 \\
(.012)\end{array}$ & $\begin{array}{c}.016 \\
(.012)\end{array}$ \\
\hline Out of the labour force 07 & $\begin{array}{c}-.142^{* *} \\
(.010)\end{array}$ & $\begin{array}{l}.019 * * \\
(.008)\end{array}$ & $\begin{array}{c}-.074 * * * \\
(.016)\end{array}$ & $\begin{array}{c}-.031^{* *} \\
(.008)\end{array}$ \\
\hline Out $07 *$ Permanent contract & $\begin{array}{c}-.114 * * * \\
(.024)\end{array}$ & $\begin{array}{c}-.096 * * * \\
(.018)\end{array}$ & $\begin{array}{l}-.011 \\
(.030)\end{array}$ & $\begin{array}{l}-.096 \\
(.018)\end{array}$ \\
\hline Out $07 *$ Mother & $\begin{array}{l}-.017 \\
(.035)\end{array}$ & $\begin{array}{l}-.019 \\
(.027)\end{array}$ & $\begin{array}{l}.008 \\
(.046)\end{array}$ & $\begin{array}{l}-.011 \\
(.045)\end{array}$ \\
\hline Out $07 *$ Mother*Permanent & $\begin{array}{l}.079 \\
(.063)\end{array}$ & $\begin{array}{l}-.002 \\
(.048)\end{array}$ & $\begin{array}{l}.051 \\
(.073)\end{array}$ & $\begin{array}{c}.036 \\
(.071)\end{array}$ \\
\hline
\end{tabular}

*** Significant at 1\% level; ** Significant at 5\% level; * Significant at 10\% level;. UNADJUSTED -age dummies. All covariates: Age, experience (and square), tenure (and square), industry, occupation dummies, public worker, number of workers in the firm, region dummies. 
Table A.2: Subsidies for conversion of fixed-term contracts into open-ended ones, by region and year

\begin{tabular}{|c|c|c|c|c|}
\hline Region/Year & 1997 & 1998 & 1999 & 2000 \\
\hline 1. Andalucia & \multicolumn{4}{|c|}{$\begin{array}{c}\text { Between } 1997 \text { and 2000: 4,200 if age }<\text { or }=30 ; 3,000 \text { if female }>30 ; 2,400 \text { if } \\
\text { male }>30\end{array}$} \\
\hline 2. Aragon & None & $\begin{array}{l}4,200 \text { if female or } \\
\text { age }>45 \\
3,000 \text { if male } \\
41<=\text { age }<=44\end{array}$ & $\begin{array}{l}5,160 \text { if female or } \\
\text { age }>45 \\
4,500 \text { if } \\
41<=\text { age }<=44 \\
3,600 \text { if male } \\
\text { age }<30\end{array}$ & $\begin{array}{l}5,160 \text { if female or } \\
\text { age }>45 \\
4,500 \text { if } \\
41<=\text { age }<=44 \\
3,600 \text { if male } \\
\text { age }<46\end{array}$ \\
\hline 3. Asturias & 4,500 for all & 4,500 for all & None & $\begin{array}{l}4,200 \text { if female or } \\
\text { age }>=46 \\
3,600 \text { otherwise }\end{array}$ \\
\hline 4. Baleares & None & None & None & $1,652.78$ if female \\
\hline 5. Canarias & None & $\begin{array}{l}3,600 \text { if female or } \\
\text { age }<=25\end{array}$ & $\begin{array}{l}3,600 \text { if female or } \\
\text { age }<=25 \\
3,000 \text { otherwise }\end{array}$ & None \\
\hline 6. Cantabria & None & $\begin{array}{l}3,900 \text { if female or } \\
\text { age }<=30 \\
3,300 \text { if male } \\
30<\text { age }<=40 \\
3,600 \text { if male } \\
\text { age }>=41\end{array}$ & None & $\begin{array}{l}5,408 \text { if age }>=46 \\
3,606 \text { if age }<=30 \\
2,163 \text { otherwise }\end{array}$ \\
\hline 7. Castilla-Leon & None & $\begin{array}{l}5,112 \text { if female or } \\
\text { age }<30 \\
3,300 \text { rest of males }\end{array}$ & $\begin{array}{l}5,115 \text { if age }<30 \\
3,900 \text { if female } \\
\text { age }>=30 \\
1,800 \text { if male age } \\
>=41\end{array}$ & $\begin{array}{l}4,507.59 \text { if age }<30 \\
3,305.57 \text { if female } \\
\text { age }>=31 \\
1,803 \text { if male } \\
\text { age }>=41\end{array}$ \\
\hline $\begin{array}{l}\text { 8. Castilla-La } \\
\text { Mancha }\end{array}$ & None & $\begin{array}{l}3,600 \text { if females } \\
3,000 \text { if age }<30\end{array}$ & None & $\begin{array}{l}3,600 \text { if female } \\
3,000 \text { if age }>45 \text { or } \\
\text { age }<30\end{array}$ \\
\hline 9. Valencia & None & $30 \%$ of payroll tax & $30 \%$ of payroll tax & $30 \%$ of payroll tax \\
\hline 10. Extremadura & $\begin{array}{l}10,655.94 \text { if age } \\
<\text { or }=45 \\
13,402 \text { if } \\
\text { age }>45\end{array}$ & $\begin{array}{l}10,100 \text { if age }<=30 \\
11,180 \text { if age }>30 \\
\text { and age }<=40 \\
14,027 \text { if age }>40\end{array}$ & $\begin{array}{l}14,027.62 \text { if } \\
\text { age }>46 \\
11,178.83 \text { if } \\
\text { age }<45\end{array}$ & $\begin{array}{l}52,17.076 \text { if female } \\
\text { age }>46 \\
4,296.416 \text { if male } \\
\text { age }>46\end{array}$ \\
\hline 11. Galicia & None & $\begin{array}{l}4,200 \text { euro if } \\
\text { female or age }<30 \\
3,000 \text { if age }>45\end{array}$ & None & None \\
\hline 12. Madrid & None & $\begin{array}{l}6,000 \text { euro if } \\
\text { female } \\
6,000 \text { euro if } \\
\text { age }<30 \text { or age }>40\end{array}$ & $\begin{array}{l}7,800 \text { if female } \\
7,800 \text { if age }<25 \text { or } \\
\text { age }>40\end{array}$ & $\begin{array}{l}9,000 \text { if female } \\
6,600 \text { if age }<25 \text { or } \\
\text { age }>40\end{array}$ \\
\hline 13. Murcia & None & $\begin{array}{l}1,800 \text { for all } \\
2,400 \text { if age }<30\end{array}$ & $\begin{array}{l}1,800 \text { for all } \\
2,100 \text { if age }<30\end{array}$ & $\begin{array}{l}1,800 \text { for all } \\
2,100 \text { if age }<30\end{array}$ \\
\hline 14. Basque country & None & 7,512 for all & 7,512 for all & 7,512 for all \\
\hline 15. Rioja & None & 4,500 for all & 4,491 for all & 6,011 for all \\
\hline
\end{tabular}


Table A.2: Subsidies for conversion of fixed-term contracts into open-ended ones, by region and year (continued)

\begin{tabular}{|c|c|c|c|c|}
\hline Region/Year & 2001 & 2002 & 2003 & 2004 \\
\hline 1. Andalucia & $\begin{array}{l}4,200 \text { if age }<30 \\
3,000 \text { if females } \\
>30 \\
2,400 \text { if males }>30\end{array}$ & $\begin{array}{l}6,012 \text { for females } \\
\text { of age }<30 \\
3,607 \text { if male } \\
\text { age }>40\end{array}$ & None & None \\
\hline 2. Aragon & $\begin{array}{l}5,160 \text { if female or } \\
\text { age }>45 \\
4,500 \text { if age }>=41 \\
3,600 \text { if male } \\
\text { age }<30\end{array}$ & $\begin{array}{l}4,500 \text { if female } \\
4,125 \text { if age }<30 \text { or } \\
\text { age }>=41\end{array}$ & $\begin{array}{l}4,500 \text { if female } \\
4,125 \text { if age }<30 \text { or } \\
\text { age }>=41\end{array}$ & $\begin{array}{l}3,750 \text { for all and } \\
7,250 \text { if female }\end{array}$ \\
\hline 3. Asturias & $\begin{array}{l}4,200 \text { if female or } \\
\text { age }>=46 \\
3,600 \text { otherwise }\end{array}$ & $\begin{array}{l}4,200 \text { if female of } \\
\text { age }>46 \\
3,600 \text { otherwise }\end{array}$ & $\begin{array}{l}4,200 \text { if female of } \\
\text { age }>46 \\
3,600 \text { otherwise }\end{array}$ & None \\
\hline 4. Baleares & $\begin{array}{l}1,652.78 \text { for } \\
\text { females }\end{array}$ & 1,800 for females & 4,808 for females & 4,808 for females \\
\hline 5. Canarias & None & None & None & None \\
\hline 6. Cantabria & \multicolumn{4}{|c|}{$\begin{array}{c}4,808 \text { for females } \\
3,005 \text { if male age }<=30 \\
4,207 \text { if age }>45,1,803 \text { otherwise }\end{array}$} \\
\hline 7. Castilla-Leon & \multicolumn{4}{|c|}{$\begin{array}{c}4,507.59 \text { if age }<30 \\
3,305.57 \text { if female age }>31 \\
1,803 \text { if male age }>41 \\
\end{array}$} \\
\hline $\begin{array}{l}\text { 8. Castilla-La } \\
\text { Mancha }\end{array}$ & \multicolumn{4}{|c|}{$\begin{array}{c}3,600 \text { if female } \\
3,000 \text { if age }>45 \text { or age }<30\end{array}$} \\
\hline 9. Valencia & $4,808.1$ for all & 1,800 for females & $\begin{array}{l}2,000 \text { for females } \\
1500 \text { for the rest }\end{array}$ & $\begin{array}{l}4,000 \text { if female } \\
2,000 \text { if age }<30\end{array}$ \\
\hline 10. Extremadura & $\begin{array}{l}5,410.086 \text { if } \\
\text { female }>45 \\
4,455.365 \text { if male } \\
>45 \\
2,386.802 \\
\text { otherwise }\end{array}$ & 6,010 for all & None & None \\
\hline 11. Galicia & None & None & $\begin{array}{l}4,200 \text { euro if } \\
\text { female or age }<30 \\
2,400 \text { if age }>45 \\
3,000 \text { if age }>24 \& \\
\text { age }<45\end{array}$ & $\begin{array}{l}4,500 \text { if female or } \\
\text { age }>50 \\
3,000 \text { if } 25<\text { age }<50\end{array}$ \\
\hline 12. Madrid & 10,800 for all & 12,000 for all & 9,000 for all & 3,000 for all \\
\hline 13. Murcia & 4,800 for all & 4,800 for all & None & None \\
\hline 14. Basque country & 7,512 for all & 7,512 for all & 7,512 for all & $\begin{array}{l}\text { 6,000 for males, } \\
7,500 \text { for females }\end{array}$ \\
\hline 15. Rioja & 6,011 for all & 6,011 for all & 6,011 for all & 6,011 for all \\
\hline
\end{tabular}


Table A.3

First -Stage Regression

Dependent variable is type of contract ( 1 -permanent; 0 = fixed-term)

\begin{tabular}{|c|c|}
\hline & $\begin{array}{l}\text { Coeff. } \\
\text { (S.E.) }\end{array}$ \\
\hline Instrument & $\begin{array}{c}.112^{* * *} \\
(.010)\end{array}$ \\
\hline Full-time & $\begin{array}{c}.357^{* * * *} \\
(.009)\end{array}$ \\
\hline High School degree & $\begin{array}{c}.011^{* * *} \\
(.003) \\
\end{array}$ \\
\hline College degree & $\begin{array}{c}.021 * * * \\
(.005)\end{array}$ \\
\hline Experience & $\begin{array}{l}.041^{* * *} \\
(.001)\end{array}$ \\
\hline Experience $^{2}$ & $\begin{array}{c}-.001^{* * *} \\
(.000)\end{array}$ \\
\hline Tenure & $\begin{array}{c}.061^{* * * *} \\
(.001)\end{array}$ \\
\hline Tenure $^{2}$ & $\begin{array}{c}-.002^{* * *} \\
(.000)\end{array}$ \\
\hline Public sector & $\begin{array}{c}.086^{* * *} \\
(.005)\end{array}$ \\
\hline Firm size & $\begin{array}{c}-8.18 \mathrm{e}-06^{* * *} \\
(5.71 \mathrm{e}-07)\end{array}$ \\
\hline R2 & .41 \\
\hline N. Observations & 310,944 \\
\hline
\end{tabular}

